\title{
Long-term trends of sulfur deposition in East Asia during 1981-2005
}

\author{
Masatoshi Kuribayashi ${ }^{a, 1}$, Toshimasa Ohara ${ }^{b, *}, \mathrm{Yu}$ \\ Morino $^{b}$, Itsushi Unoc, Jun-ichi Kurokawad, Hiroshi \\ Harae $^{\mathrm{e}}$
}

a Graduate School of Life and Environmental Sciences, University of Tsukuba, 1-1-1 Tennoudai, Tsukuba, Ibaraki 305-8577, Japan

b National Institute for Environmental Studies, 16-2 Onogawa, Tsukuba, Ibaraki 305-8506, Japan

c Research Institute for Applied Mechanics, Kyushu University, Kasuga Park 6-1, Kasuga, Fukuoka 816-8580, Japan

d Asia Center for Air Pollution Research, 1182 Sowa, Nishi-ku, Niigata, Niigata 950-2144, Japan

e Tokyo University of Agriculture and Technology, 3-5-8 Saiwaicho, Fuchu, Tokyo 183-8509, Japan

* Corresponding author. Tel.: +81-29-850-2491; fax: +81-29-850-2569 E-mail address: tohara@nies.go.jp (T. Ohara).

${ }^{1}$ presently at River Basin Research Center, Gifu University, 1-1 Yanagido, Gifu 501-1193, Japan 
3 We used a chemical transport model to investigate the long-term 4 trends of sulfur deposition in East Asia during 1981-2005. The model 5 reproduced the observed spatial distributions in East Asia of the rate 6 of wet deposition of non-seasalt sulfate (nss-SO ${ }_{4}^{2-}$ ), volume-weighted 7 mean concentrations of $\mathrm{nss}^{-} \mathrm{SO}_{4}{ }^{2-}$ in precipitation, precipitation, and concentrations in air of gaseous sulfur dioxide and particulate 9 nss-SO ${ }_{4}^{2-}$. The model also reproduced well observed seasonal variations and long-term trends of wet deposition of $\mathrm{nss}^{-} \mathrm{SO}_{4}{ }^{2-}$ in

11 Japan from 1988 to 2005. The increasing rate of wet deposition of $12 \mathrm{nss}^{-\mathrm{SO}_{4}}{ }^{2-}$ in Japan during 1991-2005 was demonstrated with $99.9 \%$ 13 significance for both observed and modeled data. The annual rate of 14 total (wet + dry) sulfur deposition in Japan increased from 15.6 Gmol

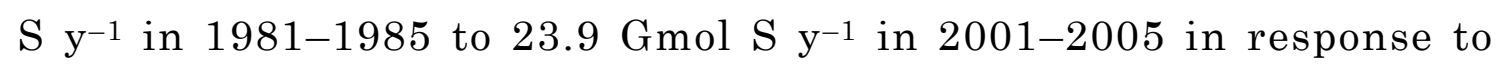
both increasing contributions from Chinese emissions and the eruption of Miyakejima volcano in 2000. During that 25-year period, approximately $2.1 \%$ of the sulfur from Chinese emissions was deposited in Japan. Over the same period, the rate of deposition of sulfur in East Asia increased gradually from $14.2 \mathrm{mmol} \mathrm{S} \mathrm{m}^{-2} \mathrm{y}^{-1}$ to $24.0 \mathrm{mmol} \mathrm{S} \mathrm{m}^{-2} \mathrm{y}^{-1}$, and the contribution of emissions from China to total sulfur deposition in East Asia increased from 65\% to 77\%. The contribution of Miyakejima volcano was 3\% during 2001-2005. The

24 increase in the sulfur deposition rate was remarkably high on the

25 North China Plain, around Guangzhou, and south of Chongqing. The 26 rate of increase in East Asia was greatest in winter, although the 
27 rate of sulfur deposition was highest in summer. Sulfur flux from 28 China to Japan increased by a factor of 2.5 at altitudes of $0-3000 \mathrm{~m}$ 29 from 1981 to 2005.

30

31 Keywords: Sulfur deposition; Long-term trends; East Asia; Chemical 32 transport model; China; Miyakejima volcano 


\section{Introduction}

Deposition of atmospheric sulfur causes acidification of soil and water, which is harmful to ecosystems (Krug and Frink, 1983; Likens et al., 1996); thus, it is important to understand spatiotemporal variations of rates of sulfur deposition. Dentener et al. (2006) showed that, in global terms, the regions worst affected by sulfur deposition are North America, Europe, and Asia. Observations of sulfur deposition by national and international networks (European Monitoring and Evaluation Programme and National Atmospheric Deposition Program/National Trends Network) have revealed that sulfur deposition rates in Europe and North America have decreased since the 1970s because of continuous decreases of sulfur dioxide $\left(\mathrm{SO}_{2}\right)$ emissions in those regions (Likens et al., 2001; Fowler et al., 2007). In Asia, by contrast, $\mathrm{SO}_{2}$ emissions from China, which account for $64-71 \%$ of the total emissions from Asia, increased rapidly from the 1980s to the mid-1990s, decreased slightly during 1995-1999, and increased dramatically in the early 2000s (Ohara et al., 2007; Lu et al., 2010). Since 1992, Asia's contribution to global $\mathrm{SO}_{2}$ emissions has been greater than any other region (Stern, 2005). Although modeling by Carmichael et al. (2002) indicated that the rate of sulfur deposition in Asia increased during 1975-2000, there were no monitoring programs covering the entire Asian continent during that 25-year period.

In 1983, the Japan Environment Agency (now the Ministry of the Environment) started a nationwide monitoring network, the Japanese Acid Deposition Survey (JADS). JADS data indicated that the wet deposition rate of non-seasalt sulfate (nss-SO ${ }_{4}^{2-}$ ) in Japan decreased significantly from 1989 to 1998 (Seto et al., 2004). In 2000, monitoring of atmospheric deposition by the Acid Deposition Monitoring Network in East Asia (EANET) commenced, with the aim of creating a common understanding of acid deposition problems in East Asia. Seto et al. (2007) analyzed EANET data from 2000-2004 and showed that continental emissions made a large contribution to wet deposition of $\mathrm{nss}^{-} \mathrm{SO}_{4}{ }^{2-}$ over remote areas in Japan during 
high-deposition episodes. Considering the rapid increase of $\mathrm{SO}_{2}$ emissions in China during 2000-2005 and the huge $\mathrm{SO}_{2}$ emissions from the eruption of Miyakejima volcano in 2000 (Kajino et al., 2004; Lu et al., 2010), there is a need to evaluate the trends of deposition of atmospheric sulfur in East Asia, particularly since 2000 .

Chemical transport models (CTMs) can provide a comprehensive understanding of air pollution by simulating emissions, transportation, chemical and aerosol processes, and deposition. CTMs are useful tools for evaluating the factors controlling sulfur deposition as they can differentiate deposition processes (e.g., dry or wet, gaseous or particulate) and quantify source contributions. Several studies have estimated region-to-region source-receptor (S/R) relationships for sulfur deposition in East Asia (e.g., Arndt et al., 1998; Ichikawa et al., 1998; Lin et al., 2008) and improved our understanding of origin of sulfur deposited in East Asia. However, few modeling studies have addressed the need to understand the factors that control the long-term trends of sulfur deposition in East Asia.

We evaluated the long-term trends of sulfur deposition in East Asia during 1981-2005 by using a Community Multiscale Air Quality (CMAQ) model and Regional Emission inventory in Asia (REAS) data. Our objective was to characterize the long-term trends of sulfur deposition. First, we compared the results of our simulations with observational data (Section 3.1). Then, we determined the long-term trends of the rate of sulfur deposition in Japan from both the observed and simulated data and quantified the source contributions (Sections 3.1 and 3.2). We also considered spatial and seasonal variations of sulfur deposition in East Asia (Sections 3.3 and 3.4). Finally, we evaluated the vertical variations of atmospheric sulfur from various sources during 1981-2005 (Section 3.5). 


\section{Data and methodology}

\subsection{Numerical model}

Our model was based on the CMAQ version 4.4 system released by the US Environmental Protection Agency (Byun and Schere, 2006). This model is driven by meteorological fields generated by the Regional Atmospheric Modeling System (RAMS) version 4.4 (Pielke et al., 1992). The domain of the CMAQ simulation covers $6240 \mathrm{~km} \times 5440 \mathrm{~km}$ on a rotated polar stereographic map projection centered at $25^{\circ} \mathrm{N}, 115^{\circ} \mathrm{E}$ (Fig. 1), with $80 \mathrm{~km} \times$ $80 \mathrm{~km}$ grid resolution and a 14-layer vertical structure up to an elevation of $23 \mathrm{~km}$ set on a terrain following the sigma-z coordinate system.

We adopted the Statewide Air Pollution Research Center 99 scheme (Carter, 2000) for gas-phase chemistry. The dry deposition velocity of gaseous species is defined as the reciprocal of the sum of the aerodynamic resistance, the quasilaminar sublayer resistance, and the bulk surface resistance (Wesely, 1989).

For aerosol calculations, we applied the third-generation CMAQ aerosol module, which includes the ISORROPIA model (Nenes et al., 1998) as an inorganic aerosol model, and the piecewise parabolic method of Binkowski and Shankar (1995) as the regional particulate model. In addition, the cloud scheme in CMAQ complies in basic terms with the diagnostic model used in the Regional Acid Deposition Model of Chang et al. (1987).

Meteorological fields for each year were generated using RAMS with initial and boundary conditions defined by National Centers for Environmental Prediction-National Center for Atmospheric Research Reanalysis 1 data sets (Kalnay et al., 1996; Kistler et al., 2001). The reanalysis data sets were available with $2.5^{\circ} \times 2.5^{\circ}$ horizontal resolution at 6-h intervals.

Initial fields of chemical compounds were prepared using the initial conditions processor of the CMAQ modeling system (Byun and Schere, 2006). Monthly averaged lateral boundary conditions for most chemical tracers were obtained from a global CTM: the Chemical Atmospheric General 
123 Circulation Model for Study of Atmospheric Environment and Radiative 124 Forcing (Sudo et al., 2002).

125 For these simulations, we prepared data sets for anthropogenic emissions 126 of $\mathrm{SO}_{2}$, nitrogen oxides, carbon monoxide, non-methane volatile organic 127 compounds, black carbon, organic carbon, and ammonia $\left(\mathrm{NH}_{3}\right)$ by using 128 REAS version 1.1 over Asia with about $0.5^{\circ} \times 0.5^{\circ}$ horizontal resolution 129 (Ohara et al., 2007). The REAS data sets include most anthropogenic sources 130 for 1980-2003, such as fuel combustion and industrial processes. 131 Additionally, we used the emission data sets for 2004 and 2005 of Kurokawa 132 et al. (2009), which extended the REAS data to 2005 using the same 133 methodology as Ohara et al. (2007). $\mathrm{SO}_{2}$ emissions in 2000 in the REAS data 134 agreed with four other emission inventories within a range from $-20 \%$ to $13536 \%$ in Asia and from $-26 \%$ to $24 \%$ in China (Ohara et al., 2007). The 136 estimate of $\mathrm{SO}_{2}$ emissions in China during 2000-2003 in the REAS data is 137 1.27-1.37 times greater than the recent estimate of $\mathrm{Lu}$ et al. (2010). These 138 results serve as an indication of emission uncertainty.

139 Streets et al. (2003) and $\mathrm{Lu}$ et al. (2011) estimated that monthly $\mathrm{SO}_{2}$ 140 emissions in China are largest in winter and that the ratio between 141 maximum and minimum monthly emissions is 1.2-1.4, whereas the REAS 142 data did not include seasonal variation of $\mathrm{SO}_{2}$ emissions. Thus, our estimate 143 may underestimate $\mathrm{SO}_{2}$ emissions in winter and overestimate them in 144 low-emission seasons by a factor of 1.1-1.2.

145 We also considered $\mathrm{SO}_{2}$ emissions from the 2000 eruption of Miyakejima 146 volcano (Kajino et al., 2004; Japan Meteorological Agency) and from 12 other 147 active volcanoes in Japan (Fujita et al., 1992). We used climatological 148 inventories of biomass burning emissions from Streets et al. (2003) and took 149 biogenic emissions of isoprene and monoterpene from monthly emissions 150 presented by Guenther et al. (1995).

151 The effective heights of the stacks of large point sources were uniformly set 152 to $240-675 \mathrm{~m}$ above ground level. Although there is uncertainty in the smoke 153 height, the influence of smoke height below $1000 \mathrm{~m}$ on dry deposition rate is 
154 not significant at distances beyond $150 \mathrm{~km}$ from the emission source 155 (Hayami and Ichikawa, 2001). The influence of smoke height on wet 156 deposition rate is expected to be smaller still, because wet deposition rate is 157 less sensitive than dry deposition to the vertical profile of atmospheric sulfur 158 concentrations. On the other hand, the effective injection height of volcanic 159 plumes was uniformly set to 1000-2500 $\mathrm{m}$ above the altitude of all active 160 volcanic craters in the study area. The influence of the effective injection 161 height (above $1000 \mathrm{~m}$ ) on sulfur deposition was not estimated in previous studies and this study. This point should be evaluated in future studies.

The modeling system we used has been applied previously for analyses of East Asian sulfur transport and deposition (Aikawa et al., 2010), nitrogen transport and deposition (Morino et al., 2011), and tropospheric ozone content (Kurokawa et al., 2009). The simulation results of these studies generally show good agreement with observational data.

We conducted three sets of numerical experiments. First, we performed a simulation from 1 January 1981 to 31 December 2005 (control run). Second, to estimate the contributions from China and Miyakejima volcano to sulfur deposition in East Asia, we conducted two perturbation runs: one with emissions from China set to zero, the other with emissions from Miyakejima volcano set to zero. We defined the individual contributions of China and Miyakejima volcano as the difference between the control run and the respective perturbation runs. All runs used the same meteorological field, initial conditions, and boundary conditions for chemical tracers. We should note that our sensitivity analyses with zero emission for all precursor species may include errors because of nonlinearity in chemical processes related to $\mathrm{NH}_{3}$. Lin et al. (2008) compared a baseline simulation to sensitivity analyses with zero emissions from different regions and showed that the experiment with zero regional emissions overestimated the contribution of wet (dry) deposition of particulate nss- $\mathrm{SO}_{4}{ }^{2-}$ by about $20 \%$ (64\%) over the baseline simulation and underestimated the contribution of dry deposition of gaseous $\mathrm{SO}_{2}$ by about $2 \%$. Thus, this nonlinearity may cause the contributions of each 
source to total sulfur deposition to be overestimated by approximately $20 \%$ in regions where the wet process is dominant.

\subsection{Observational data}

We used monthly observed data from EANET for 2000-2005 (Network center for EANET, 2006) and from JADS for 1988-2005 (Japanese Ministry of the Environment, 2002, 2009) to validate the CMAQ simulation.

\subsubsection{EANET data}

The EANET measurement sites were classified as remote, rural, or urban, where remote sites were defined as those more than $50 \mathrm{~km}$ from large pollution sources, rural sites were those between 20 and $50 \mathrm{~km}$ from such sources, and urban sites were those less than $20 \mathrm{~km}$ from such sources. We used the data from rural and remote sites in this study. Figure 1 and Table 1 provide the locations and other details of EANET monitoring sites used in this analysis. The EANET data for monthly rates of wet deposition of $\mathrm{nss}^{-} \mathrm{SO}_{4}{ }^{2-}$ and volume-weighted mean concentrations of $\mathrm{nss}^{-} \mathrm{SO}_{4}{ }^{2-}$ in precipitation satisfy the EANET criteria for completeness of precipitation data (Network center for EANET, 2006). In this analysis, we set criteria for monthly concentrations in air of gaseous $\mathrm{SO}_{2}$ and particulate $\mathrm{SO}_{4}{ }^{2-}$ (temporal data coverage of $>80 \%$ in each month). To calculate annual (seasonal) average deposition and concentration from EANET data, we excluded data where less than 7 months ( 2 months) of data were available. Details of the monitoring techniques, including sampling, chemical analysis, definitions of data completeness, and quality control and quality assurance are documented in the EANET monitoring manual (Network center for EANET, 2000a, 2000b, 2001, 2006).

\subsubsection{JADS data}

The JADS measurement sites were classified as remote, rural, and urban on the similar basis as the EANET sites (Japanese Ministry of the 
216 Environment, 2002). We used the data from rural and remote sites in this 217 analysis. The number of JADS sites has changed over time so they were 218 considered in five phases: I (1983-1987; 29 sites), II (1988-1992; 29 sites), III 219 (1993-1997; 48 sites), IV (1998-2000; 55 sites), and post-2000 (31 sites). In 220 addition, the monitoring techniques used for JADS have changed in response 221 to technical developments. The most important change was the introduction 222 of automated wet-only samplers for every site in 1988 (Japanese Ministry of 223 the Environment, 2002, 2009). 


\section{Results and discussion}

\subsection{Model validation}

3.1.1. Validation of annual means of wet deposition of sulfur, precipitation, and atmospheric sulfur concentration

The model reproduced $81 \%$ of wet deposition rates of $\mathrm{nss}^{-} \mathrm{SO}_{4}{ }^{2-}$ and $79 \%$ of nss- $\mathrm{SO}_{4}{ }^{2-}$ concentrations in precipitation within a factor of 2 (Figs. 2a and $2 \mathrm{~b}$ and Table 2). However, the model underestimated both of these in Chongqing (ID = 1 and 2; see Fig. 1 and Table 1) and Xian (ID = 3-5) in China, yielding results smaller than observations by factors of about 2-6 (Table 2). At Jinyunshan in Chongqing, the model also underestimated precipitation and gaseous $\mathrm{SO}_{2}$ concentrations (Figs. 2c and $2 \mathrm{~d}$ ), suggesting that the model did not capture the local structure of pollution and precipitation. The model better reproduced precipitation and gaseous $\mathrm{SO}_{2}$ concentrations at Weishuiyuan in Xian. As shown in Figure 3, observed wet deposition rates of $\mathrm{nss}^{-\mathrm{SO}_{4}}{ }^{2-}$ at Weishuiyuan drastically decreased from 2003 to 2004 , and the model better reproduced the observations in year 2004 and 2005. The cause of this drastic decrease is undetermined.

In contrast, the model overestimated both the wet deposition rate and concentration in precipitation of $\mathrm{nss}^{-} \mathrm{SO}_{4}{ }^{2-}$ by a factor of 5 at Chiang Mai, Thailand (Figs. 2a and 2b and Table 2), possibly because of overestimation of $\mathrm{SO}_{2}$ emissions from a coal-fired power generation plant at a mine in Mae Moh district about $90 \mathrm{~km}$ southeast of Chiang Mai. Installation of a flue-gas desulfurization system at the Mae Moh power plant in 2000 may have reduced $\mathrm{SO}_{2}$ emissions by as much as 90-97\% (Sampattagul et al., 2005); REAS data do not reflect this change.

The simulation reproduced $79 \%$ of observed annual precipitation values within a factor of 2 (Fig. 2c), but the model consistently underestimated precipitation at sites in China, Japan, Mongolia, and Korea (Table 2). In Japan, these underestimates were greater at the southern sites (ID = 13-16) than at the other sites (ID = 7-12) (Table 2). In addition, Yoshida et al. (2006) showed that RAMS, using the same setup as this study, reproduced the 
256 temporal variations of temperature, wind speed, and precipitation well in 257 East Asia but underestimated the total precipitation amount in Japan and the Pacific Ocean by $20-40 \%$.

The model reproduced $60 \%$ and $75 \%$ of the observed concentrations of gaseous $\mathrm{SO}_{2}$ and particulate $\mathrm{SO}_{4}{ }^{2-}$, respectively, within a factor of 2 (Figs. $2 \mathrm{~d}$ and $2 \mathrm{e}$ ). The model could not reproduce the gaseous $\mathrm{SO}_{2}$ concentrations at Ijira, Japan (ID = 12), and at sites in Mongolia, Russia, and Southeast Asia (ID $=21,25-27)$ (Fig. 2d). There are two possible explanations for the underestimations in Mongolia and Russia. First, these sites are close to the northern boundary of the model domain (Fig. 1) and are thus strongly influenced by the lateral boundary condition ( $\mathrm{SO}_{2}$ concentration close to zero). Second, the REAS data sets do not include emission sources in Russia. The modeled concentrations of particulate $\mathrm{SO}_{4}{ }^{2-}$ overestimated observed concentrations by a factor of 1.5 at most sites in Japan (Table 2), and observation data for particulate $\mathrm{SO}_{4}{ }^{2-}$ concentrations are not available for China and Korea.

\subsubsection{Validation of seasonal variations in wet deposition rates of $\mathrm{nSS}^{-} \mathrm{SO}_{4}{ }^{2-}$}

Comparison of simulated monthly wet deposition rates of $\mathrm{nss}^{-} \mathrm{SO}_{4}{ }^{2-}$ with observed data at representative EANET sites in each country shows that the model has successfully reproduced observed seasonal variations at all sites except Weishuiyuan (Fig. 3). The problem in Weishuiyuan is discussed in Section 3.1.1.

Scatter plots comparing observed and simulated average seasonal wet deposition rates of $\mathrm{nss}^{-\mathrm{SO}_{4}}{ }^{2-}$ (Fig. 4) show that the model reproduced $57 \%$, $67 \%, 68 \%$, and $44 \%$ of $\mathrm{nss}^{-} \mathrm{SO}_{4}{ }^{2-}$ wet deposition within a factor of 2 in spring (Mar-May), summer (June-Aug), autumn (Sept-Nov), and winter (Dec-Feb), respectively. The consistency between observations and the model is worse for seasonal data than for annual data. As shown in Section 3.1.1, observed annual wet deposition rates of $\mathrm{nss}^{-} \mathrm{SO}_{4}{ }^{2-}$ were largely underestimated in 
287 in all seasons in China and in three seasons other than winter at Chiang Mai

288 (Fig. 4). The model did not overestimate wet deposition at Chiang Mai in 289 winters with little rain. In Japan and Korea, the model generally reproduced 290 seasonal variations well. It reproduced wet deposition rates in spring at 291 almost all stations within a factor of 2 (Fig. 4a). However, it underestimated 292 rates observed in southern Japan (ID $=12,14-16$ ) in summer because of 293 underestimation of precipitation. It also overestimated wet deposition rates 294 observed in northern Japan (ID = 7, 8) in autumn, and at Imsil, Korea, in 295 winter, as a result of overestimating $\mathrm{nss}^{-} \mathrm{SO}_{4}{ }^{2-}$ concentration in precipitation. 296 In the northwestern part of the CMAQ domain (ID = 17, 23, 24) and 297 Southeast Asia (ID = 21, 25, 26), the discrepancies between observations and 298 simulations were large in winter (Fig. 4d). However, the wet deposition rate 299 of $\mathrm{nss}^{-\mathrm{SO}_{4}}{ }^{2-}$ is small in winter as a result of low precipitation (Fig. 3), thus 300 these discrepancies do not affect the model performance for annual wet 301 deposition rates of $\mathrm{nss}^{-} \mathrm{SO}_{4}{ }^{2-}$.

302

303 304

3.1.3. Validation of long-term trends of the rate of wet deposition of $\mathrm{nSS}_{\mathrm{S}} \mathrm{SO}_{4}{ }^{2-}$ in Japan

Comparison of simulated and JADS observed long-term trends of wet 306 deposition rates of $\mathrm{nss}^{-} \mathrm{SO}_{4}{ }^{2-}$ in Japan show that the model reproduced well monthly variations (Fig. 5a), although it underestimated some local maxima in the JADS data. Discrepancies between observed data and modeled annual average deposition rates are less than the range of the standard deviation (Fig. 5b). The simulation agreed better with observed monthly data after 1991, when the number of observation sites increased from 7 to 12 (Fig. 5a). Simulation results averaged over the grids including the observation sites also agreed with the model data averaged over all of Japan (117 grids) after 1991, but not before 1991 (Fig. 5b). These results suggest that JADS data averaged over fewer than 10 observation sites may poorly represent the deposition rates over all of Japan. Therefore, we compared the observed and simulated long-term trends of sulfur deposition rates after 1991. 
The annual increase rates of observed and simulated (average of grids over observation sites) monthly wet deposition of $\mathrm{nss}^{-} \mathrm{SO}_{4}{ }^{2-}$ during $1991-2005$ were $1.96 \% \mathrm{y}^{-1}$ and $3.04 \% \mathrm{y}^{-1}$, respectively (Fig. 5a). These rates were calculated as a percentage of a linear regression coefficient to the average during the 25-year period. Applying the Student's $t$-test to these rates, the $t$ values of both the observed trend ( $t$ value: 3.74 for 177 degrees of freedom) and simulated trend ( $t$ value: 6.85 for 177 degrees of freedom) exceeded the 0.001 significance level ( $t$ value: 3.35 for 177 degrees of freedom) and can be considered statistically significant (99.9\%). On the other hand, the corresponding annual increase rates of observed and simulated monthly precipitation during $1991-2005$ were $2.65 \% \mathrm{y}^{-1}$ and $1.82 \% \mathrm{y}^{-1}$, respectively (Fig. 5c). Therefore the model underestimated the increase rate of monthly precipitation but overestimated the increase rate of monthly wet deposition of $\mathrm{nss}^{-} \mathrm{SO}_{4}{ }^{2-}$. The overestimate of wet deposition can be partly explained by underestimations during 1991-1992 and overestimations during 2004-2005 (Fig. 5b). The increase rates of observed and simulated wet deposition during 1993-2003 were $3.56 \% \mathrm{y}^{-1}$ and $4.00 \% \mathrm{y}^{-1}$, respectively, a better match than that for 1991-2005.

\subsection{Long-term trends of sulfur deposition in Japan}

We calculated total (wet + dry) sulfur deposition in Japan from 1981 to 2005 as the sum of deposition from each $\mathrm{SO}_{2}$ emission source (China, Miyakejima volcano, and others) in 117 grids $\left(748,800 \mathrm{~km}^{2}\right)$ shown in Fig. 1. We also calculated sulfur inflow to Japan, defined as the sum of sulfur flux passing through the western edge of Japan shown in Fig. 1 from west to east or from north to south. The cross-sectional area used to calculate sulfur flow into Japan is $68,733 \mathrm{~km}^{2}$ (length: $3,200 \mathrm{~km}$, height: $21.479 \mathrm{~km}$ ).

The contribution of wet deposition to the total sulfur deposition in Japan was about $78 \%$, and the contribution of particulate $\mathrm{nss}^{-} \mathrm{SO}_{4}{ }^{2-}$ deposition was about 82\% (Fig. 6a). These values changed little during 1981-2005, and their interannual variations were less than $3 \%$. On the other hand, annual sulfur 
deposition in Japan increased from $15.6 \mathrm{Gmol} \mathrm{S}^{-1}$ during 1981-1985 to 23.9

350 Gmol S y ${ }^{-1}$ during 2001-2005 (Fig. 6a). This increase can be explained by increased contributions from China (an increase of $7.0 \mathrm{Gmol} \mathrm{S} \mathrm{y} \mathrm{y}^{-1}$ ) and Miyakejima volcano (2.4 Gmol S y $\mathrm{y}^{-1}$ ). Sulfur deposition from other sources decreased marginally $\left(-1.0 \mathrm{Gmol} \mathrm{S} \mathrm{y}{ }^{-1}\right)$. The contribution of China to the rate of sulfur deposition in Japan increased from 34\% in the early 1980 s to $51 \%$ in the early 2000s, and the contribution of Miyakejima volcano was about $10 \%$ during 2001-2005. The annual inflow of sulfur over the western edge of Japan also increased during the 25 years (Fig. 6c). The contribution of China to sulfur inflow to Japan increased from $43 \%$ in 1981 to $76 \%$ in 2005 . The interannual trend of $\mathrm{SO}_{2}$ emissions in China explains well the trend of China's contribution to sulfur deposition in Japan $(R=0.96)$ and sulfur inflow to Japan $\left(R=0.98\right.$ ) (Figs. 6a-c). Approximately $29.4 \%$ of $\mathrm{SO}_{2}$ emissions from China reached Japan (Figs. 6b and 6c), and 2.06\% of $\mathrm{SO}_{2}$ emissions from China were deposited on the 117 grids covering Japan (Figs. $6 \mathrm{a}$ and $6 \mathrm{~b})$.

For a comparison among several studies (Fig. 7), we scaled the sulfur 366 deposition in Japan by simply multiplying the ratio of a land area of Japan $\left(377,880 \mathrm{~km}^{2}\right)$ to the area of Japan defined in individual studies. The studies shown as red symbols in Fig. 7 had explicit definitions of the area of Japan: $812,800 \mathrm{~km}^{2}$ in Ikeda and Higashino (1997), and 813,000 km² in Inoue et al. (2005). Ichikawa et al. (1998) was shown as green symbol, because we could read the area of Japan $\left(610,844 \mathrm{~km}^{2}\right)$ from figures without explicit definition. The studies shown as light gray symbols did not indicate the area of Japan clearly, and thus we did not scale the results of these studies. Approximately $1.04 \%$ of $\mathrm{SO}_{2}$ emissions from China were deposited on the land area of Japan in this study (Fig. 7). It was estimated as $0.88 \%$ by Ikeda and Higashino (1997), 0.63\% by Ichikawa et al. (1998), 0.71\% by Arndt et al. (1998), 1.18\% by Carmichael et al. (2000), 0.78\% by Carmichael et al. (2002), 1.58\% by Inoue et al. (2005), and $0.42 \%$ by Lin et al. (2008) (Fig. 7). The differences among these studies should reflect differences in the defined region of Japan, 
380 the CTM used, the interannual variation of meteorology, and emission data.

381 We estimate that meteorological variation scatter these percentages less 382 than $0.42 \%$, because the percentage of Chinese emissions deposited in Japan 383 was $1.26 \%$ in 2002 (maxima) and $0.84 \%$ in 1990 (minima) in this study. The 384 percentage of Chinese emissions deposited in Japan for each season was 385 estimated to be $1.21 \%, 0.84 \%, 0.91 \%$, and $1.24 \%$, in spring, summer, autumn, 386 and winter, respectively (Fig. 7). These differences are attributed to seasonal meteorological conditions (see Section 3.4).

\subsection{Long-term trends of sulfur deposition in East Asia}

The rate of total sulfur deposition in East Asia increased remarkably from the early 1980s to the early 2000s (Fig. 8), reflecting the rapid increase of $\mathrm{SO}_{2}$ emissions from China and emissions from Miyakejima volcano (Fig. 6b). The area where China's contribution to total sulfur deposition was more than $60 \%$ extended gradually from the coast of the Asian continent to the west coast of Japan during 1981-2005 (Figs. 8a-e), and the contribution of Miyakejima volcano was 10-20\% in eastern Japan during 2001-2005 (Fig. $8 \mathrm{f})$. The rates and source contributions of sulfur deposition in East Asia are summarized in Table 3. The $9.8 \mathrm{mmol} \mathrm{S} \mathrm{m}^{-2} \mathrm{y}^{-1}$ increase of the total rate of sulfur deposition from 1981 to 2005 can be explained by the increases of contributions from China $\left(9.1 \mathrm{mmol} \mathrm{S} \mathrm{m}^{-2} \mathrm{y}^{-1}\right)$ and Miyakejima volcano (0.8 mmol S m${ }^{-2} \mathrm{y}^{-1}$ ). From 1981 to 2005 , the contribution of emissions in China to sulfur deposition rates in East Asia increased from 65\% to 77\% and sulfur deposition from China emissions doubled. The emissions from Miyakejima volcano contributed to $3 \%$ of the rate of sulfur deposition in East Asia during 2001-2005.

The areas of high sulfur deposition during 1981-2005 did not clearly correspond to the areas of large increase rates of sulfur deposition (Figs. 9a and $b$ ). The increase rate of sulfur deposition was more than $3 \% \mathrm{y}^{-1}$ on the 409 North China Plain, the south region of $25^{\circ} \mathrm{N}$ in China, the south of 
411 Miyakejima volcano was caused by the sudden eruption of 2000 , whereas the 412 considerable increase in China was caused by steady growth of $\mathrm{SO}_{2}$ 413 emissions in China during 1981-2005 (Ohara et al., 2007), which was 414 greatest in the North China Plain (Lu et al., 2010). Growth rates of $\mathrm{SO}_{2}$ and $415 \mathrm{NH}_{3}$ emissions are both important for analyses of the nonlinearities of the 416 S/R relationship (Fowler et al., 2007). REAS estimated growth rates of $\mathrm{SO}_{2}$ 417 and $\mathrm{NH}_{3}$ emissions in East Asia during 1981-2005 as 2.98\% $\mathrm{y}^{-1}$ and 1.90\% $418 \mathrm{y}^{-1}$, respectively (Kurokawa et al., 2009).

$419 \quad \mathrm{SO}_{2}$ emissions from China made the predominant contribution (>90\%) to 420 the increased rate of sulfur deposition over the Asian continent (Fig. 9b). In 421 Japan, emissions from both China and Miyakejima volcano contributed to the increasing trend. Emissions from China were the main contributor (90\%) to the increases to the west of the coast of Japan, whereas both China $(<60 \%)$ and Miyakejima volcano contributed to the increase to the east of Japan. Even though Taiwan is close to mainland China, the increase rate of the amount of sulfur deposition indicated negative value (Fig. 9b). This might be attributed partly to the location of Taiwan in the trade wind zone windward of the mainland and partly to decreasing $\mathrm{SO}_{2}$ emissions in Taiwan (Streets and Waldhoff, 2000).

The proportion of wet deposition in total sulfur deposition from 1981 to 2005 was more than $85 \%$ on the Japan Sea side of northern Japan and northeastern China, and less than $40 \%$ in the coast of the North China Plain and Chongqing (Fig. 9c). The proportion of wet deposition was relatively high in areas of high rainfall (Figs. 9c and 9d).

The total rate of wet deposition was approximately twice the total rate of dry deposition in East Asia (Table 4). Wet deposition of sulfur was dominated by particulate $\mathrm{nss}^{-} \mathrm{SO}_{4}{ }^{2-}$, whereas dry deposition was associated with gaseous $\mathrm{SO}_{2}$. During 1981-2005 in East Asia, the rate of dry deposition of gaseous $\mathrm{SO}_{2}$ increased by a factor of 2.1 and the rate of wet deposition of particulate nss- $\mathrm{SO}_{4}{ }^{2-}$ increased by a factor of 1.5 . The share of the increase in wet deposition to the increase in total sulfur deposition was more than $75 \%$ 
442 in Japan and northeastern China, less than 50\% in the North China Plain 443 and south of Chongqing, and $50-75 \%$ south of $25^{\circ} \mathrm{N}$ in China (Fig. 9e).

3.4. Seasonal variations of sulfur deposition and long-term trends in East Asia

Average seasonal sulfur deposition rates over East Asia during 1981-2005 were 4.7, 5.7, 4.3, and $3.8 \mathrm{mmol} \mathrm{S} \mathrm{m}^{-2}$ (3 months)-1, for spring (Mar-May), summer (Jun-Aug), autumn (Sep-Nov), and winter (Dec-Feb), respectively. Sulfur deposition was highest in summer over the Asian continent, reflecting high precipitation in summer (Figs. 10a-d). In Japan, the rate of sulfur deposition was $6.8,6.2,6.0$, and $5.7 \mathrm{mmol} \mathrm{S} \mathrm{m}^{-2}$ (3 months)-1, for spring, summer, autumn, and winter, respectively. The amount of sulfur coming from China to Japan was greater in spring and winter than in summer and autumn (Fig. 7). Sulfur deposition was highest along the Japan Sea coast in winter because of the influence of the winter monsoon (Fig. 10d).

The rate of increase in annual sulfur deposition averaged over East Asia was $2.34 \% \mathrm{y}^{-1}, 2.55 \% \mathrm{y}^{-1}, 2.65 \% \mathrm{y}^{-1}$, and $2.79 \% \mathrm{y}^{-1}$ for spring, summer, autumn, and winter, respectively. The corresponding increases in Japan were $2.10 \% \mathrm{y}^{-1}, 2.24 \% \mathrm{y}^{-1}, 2.53 \% \mathrm{y}^{-1}$, and $1.95 \% \mathrm{y}^{-1}$. The rate of increase around Guangzhou and on the North China Plain was higher in summer and winter than in spring and autumn (Figs. 10e-h). The rate of increase over Japan was higher in autumn than in other seasons, owing to the influence of Miyakejima volcano on deposition in Japan in autumn (Figs. 10e-h). The share of the increase in wet deposition to the increase in annual sulfur deposition was greatest in summer and smallest in winter over most of East Asia (Figs. 10i-l).

\subsection{Vertical profile of atmospheric sulfur over Japan and sulfur flux from the} west

To our knowledge, no previous study has investigated the contribution of 472 the various sources of $\mathrm{SO}_{2}$ and particulate $\mathrm{nss}^{-} \mathrm{SO}_{4}{ }^{2-}$ to the vertical 
473 distribution of sulfur in the atmosphere over the Japan Sea and East China 474 Sea. We examined the contributions of three sources (China, Miyakejima volcano, and "others") to the vertical distribution of sulfur concentrations over Japan and to sulfur flux across the western edge of Japan for 1981-1985 and 2001-2005 (Fig. 11). Our data show that 34\% (34\%), 57\% (59\%), and 72\% $(72 \%)$ of sulfur compounds (particulate $\mathrm{nss}^{-} \mathrm{SO}_{4}{ }^{2-}$ ) over Japan occurred below 1000, 2000, and $3000 \mathrm{~m}$ altitude, respectively (Fig. 11a). By contrast, lidar measurements indicated that spherical aerosols occurred mostly below 2000 $\mathrm{m}$ at Tsukuba $\left(36.05^{\circ} \mathrm{N}, 140.12^{\circ} \mathrm{E}\right)$, Nagasaki $\left(32.81^{\circ} \mathrm{N}, 129.85^{\circ} \mathrm{E}\right)$, and Hedo (Shimizu et al., 2004; Hara et al., 2011). This result suggests that the model overestimated the fraction of $\mathrm{nss}^{-} \mathrm{SO}_{4}{ }^{2-}$ above $2000 \mathrm{~m}$ to a total vertical column abundance of $\mathrm{nss}^{-} \mathrm{SO}_{4}{ }^{2-}$, since particulate $\mathrm{SO}_{4}{ }^{2-}$ is a major component of aerosols (Topping et al., 2004).

The simulated contribution of emissions from China to sulfur concentrations over Japan was $28 \%$ at the surface and $44 \%$ at $1500-2000 \mathrm{~m}$ altitude during 1981-1985 (Fig. 11a). The contribution from China to sulfur flux was 53\% at the surface and 67\% at 1500-2000 m during 1981-1985 (Fig. 11b). The simulated sulfur concentration below $5000 \mathrm{~m}$ increased remarkably from 1981-1985 to 2001-2005 in response to increased emissions from China and the eruption of Miyakejima volcano (Figs. 11a and c). The contribution of sulfur from China below $3000 \mathrm{~m}$ was about 2.2 times higher in 2001-2005 than in 1981-1985 (Figs. 11a and c). On the other hand, sulfur concentrations from other sources below $1500 \mathrm{~m}$ decreased 25\% during this period. Sulfur flux from China to Japan below $3000 \mathrm{~m}$ was 2.5 times higher in 2001-2005 than in 1981-1985. Contributions of particulate $\mathrm{nss}^{-} \mathrm{SO}_{4}{ }^{2-}$ to the total sulfur concentration and the total incoming sulfur flux decreased slightly over the 25 years (Fig. 11). 
501

502

503

504

505

506

507

508

509

510

511

512

513

514

515

516

517

518

519

520

521

522

523

524

525

526

527

528

529

530

531

\section{Summary and conclusions}

To clarify the long-term trends of sulfur deposition in East Asia, we simulated spatiotemporal variations of sulfur deposition during 1981-2005. We used the CMAQ three-dimensional regional CTM coupled with the RAMS regional meteorological model and the REAS year-by-year emissions inventory for East Asia. CMAQ reproduced observed wet deposition rates of nss- $\mathrm{SO}_{4}{ }^{2-}$, nss- $\mathrm{SO}_{4}{ }^{2-}$ concentration in precipitation, precipitation, and concentrations in air of gaseous $\mathrm{SO}_{2}$ and particulate $\mathrm{SO}_{4}{ }^{2-}$ within a factor of 2 for most EANET stations in East Asia. CMAQ also reproduced well the monthly variations and long-term trends of rates of wet deposition of nss- $\mathrm{SO}_{4}{ }^{2-}$ observed at JADS stations in Japan from 1988 to 2005. The annual increase rates of observed and simulated monthly wet deposition of nss- $\mathrm{SO}_{4}{ }^{2-}$ during 1991-2005 were $1.69 \% \mathrm{y}^{-1}$ and $3.04 \% \mathrm{y}^{-1}$, respectively. Application of the Student's $t$-test showed $99.9 \%$ significance for the increasing trends evident in both JADS data and the modeled data.

The annual rate of sulfur deposition in Japan, which consists of 117 grids $\left(748,800 \mathrm{~km}^{2}\right)$, increased from $15.6 \mathrm{Gmol} \mathrm{S} \mathrm{y}{ }^{-1}$ during $1981-1985$ to 23.9 Gmol S y ${ }^{-1}$ during 2001-2005 in response to increased contributions from China (7.0 Gmol S y${ }^{-1}$ ) and from Miyakejima volcano (2.4 Gmol S y $^{-1}$ ). There was a small decrease in the rate of sulfur deposition from other sources $(-1.0$ Gmol $\mathrm{S} \mathrm{y}^{-1}$ ). The contribution of China to sulfur deposition in Japan increased from $34 \%$ during $1981-1985$ to $51 \%$ during 2001-2005; the eruption of Miyakejima volcano contributed about 10\% during 2001-2005. The contribution from China to the sulfur inflow to Japan increased from $43 \%$ in 1981 to $76 \%$ in 2005 . During this period, approximately $29.4 \%$ of $\mathrm{SO}_{2}$ emissions from China reached Japan and 2.06\% of these emissions were deposited on the 117 grids covering Japan. The China-to-Japan S/R ratio we determined was higher than those from previous modeling studies.

During 1981-1985, the rate of deposition of sulfur over the analytical domain was estimated to be $14.2 \mathrm{mmol} \mathrm{S} \mathrm{m}^{-2} \mathrm{y}^{-1}$, of which $9.3 \mathrm{mmol} \mathrm{S} \mathrm{m}^{-2} \mathrm{y}^{-1}$ originated from China. During 2001-2005, the corresponding rates were 24.0 
$532 \mathrm{mmol} \mathrm{S} \mathrm{m}{ }^{-2} \mathrm{y}^{-1}$ and $18.4 \mathrm{mmol} \mathrm{S} \mathrm{m}^{-2} \mathrm{y}^{-1}$.

533 The contribution of emissions from China to the rate of sulfur deposition in 534 East Asia increased from $65 \%$ to $77 \%$ during the 25 years covered by this 535 study. The contribution of the 2000 eruption of Miyakejima volcano was $3 \%$ 536 during 2001-2005. The increase in rate of sulfur deposition was remarkably 537 high on the North China Plain, the region south of $25^{\circ} \mathrm{N}$ in China, and the 538 area south of Chongqing. Sulfur deposition in East Asia was greatest in 539 summer, reflecting high precipitation. Sulfur deposition in Japan was 540 greatest in spring, reflecting higher transport of sulfur from China. The 541 increase in sulfur deposition over East Asia was greatest in winter.

542 We found that most of the sulfur in the atmosphere over Japan was below $5433000 \mathrm{~m}$ altitude. In Japan, atmospheric sulfur concentrations (flux) below $5443000 \mathrm{~m}$ originating from China were about 2.2 (2.5) times higher in 545 2001-2005 than in 1981-1985. Contributions of particulate nss- $\mathrm{SO}_{4}{ }^{2-}$ to total 546 sulfur concentration and the total incoming sulfur flux decreased slightly 547 over the 25 years covered by this study. 


\section{Acknowledgements}

550 We thank Mr. M. Katayama for his valuable assistance with our numerical

551 modeling. We appreciate Dr. K. Sato in providing meaningful information 552 about the quality of EANET data. 
560

561

562

563

564

565

566

567

568

569

570

571

572

573

574

575

576

577

578

579

580

581

582 583

\section{References}

Aikawa M., Ohara T., Hiraki T., Oishi O., Tsuji A., Yamagami M., Murano K., Mukai H., 2010. Significant geographic gradients in particulate sulfate over Japan determined from multiple-site measurements and a chemical transport model: impacts of transboundary pollution from the Asian continent. Atmospheric Environment 44, 381-391.

Arndt R.L., Carmichael G.R., Roorda J.M., 1998. Seasonal source-receptor relationships in Asia. Atmospheric Environment 32, 1397-1406.

Binkowski F.S., Shankar U., 1995. The regional particulate model 1. Model description and preliminary results, Journal of Geophysical Research 100 (D12), 26191-26209.

Byun D.W., Schere K.L., 2006. Review of the governing equations, computational algorithms, and other components of the models-3 community multiscale air quality (CMAQ) modeling system. Applied Mechanics Review $59,51-77$.

Carmichael G.R., Streets D.G., Ueda H., Leong C.P., 2000. ATMOS multi-year and seasonal simulations (Development of an integrated assessment tool for acid deposition in Asia: training, model validation, and upgrading (RAINS-ASIA Phase II), The overseas environmental cooperation center, Final report submitted to the world bank by the project team), Chapter 4, 4-17-4-46.

Carmichael G.R., Streets D.G., Calori G., Amann M., Jacobson M.A., Hansen J., Ueda H., 2002. Changing trends in sulfur emissions in Asia: implications for acid deposition, air pollution, and climate. Environmental Science \& Technology 36 (22), 4707-4713. 
585 Carter W.P.L., 2000. Documentation of the SAPRC-99 chemical mechanism for VOC reactivity assessment, final report, Final Report to California Air Resources Board Contract 92-329 and Contract 95-308.

Chang J.S., Brost R.A., Isaksen I.S.A., Madronich S., Middleton P., Stockwell W.R., Walcek C.J., 1987. A three-dimensional Eulerian acid deposition model: physical concepts and formulation. Journal of Geophysical Research 92 (D12), 14681-14700.

593

Dentener F., Drevet J., Lamarque J.F., Bey I., Eickhout B., Fiore A.M., 595 Hauglustaine D., Horowitz L.W., Krol M., Kulshrestha U.C., Lawrence M., Galy-Lacaux C., Rast S., Shindell D., Stevenson D., Van Noije T., Atherton C., Bell N., Bergman D., Butler T., Cofala J., Collins B., Doherty R., Ellingsen K., Galloway J., Gauss M., Montanaro V., Muller J.F., Pitari G., Rodriguez J., Sanderson M., Solmon F., Strahan S., Schultz M., Sudo K., Szopa S., Wild O., 2006. Nitrogen and sulfur deposition on regional and global scales: a multimodel evaluation. Global Biogeochemical Cycles 20 (GB4003), doi:10.1029/2005GB002672.

603

604 Fowler D., Smith R., Muller J., Cape J.N., Sutton M., Erisman J.W., Fagerli 605 H., 2007. Long-term trends in sulphur and nitrogen deposition in Europe and the cause of non-linearities. Water, Air, and Soil Pollution 7, 41-47, doi:10.1007/s11267-006-9102-x.

608

609 Fujita S., Tonooka Y., Ohta K., 1992. Annual contribution of volcanic sulfur 610 dioxide emissions to the atmosphere in Japan. Journal of Japan Society for 611 Air Pollution 27 (6), 336-343 (in Japanese).

613 Guenther A., Hewitt C.N., Erickson D., Fall R., Geron C., Graedel T., Harley 614 P., Klinger L., Lerdau M., Mckay W.A., Pierce T., Scholes B., Steinbrecher R., 
615 Tallamraju R., Taylor J., Zimmerman P., 1995. A global model of natural 616 volatile organic compound emissions. Journal of Geophysical Research 100 617 (D5), 8873-8892, doi:10.1029/94JD02950.

618

619 Hara Y., Uno I., Shimizu A., Sugimoto N., Matsui I., Yumimoto K., Kurokawa 620 J., Ohara T., Liu Z., 2011. Seasonal characteristics of spherical aerosol 621 distribution in Eastern Asia: integrated analysis using ground/space-based lidars and a chemical transport model. Scientific Online Letters on the Atmosphere 7, 121-124, doi:10.2151/sola.2011-031.

624

Hayami H., Ichikawa Y., 2001. Sensitivity of long-range transport of sulfur compounds to vertical distribution of sources. Water, Air, and Soil Pollution 627 130, 283-288.

628

Ichikawa Y., Hayami H., Fujita S., 1998. A long-range transport model for 630 East Asia to estimate sulfur deposition in Japan. Journal of Applied Meteorology 37, 1364-1374.

632

Ikeda Y., Higashino H., 1997. The estimation of acid deposition in East Asia (II) -Focused on the ratio of source contribution of the deposition-. Journal of Japan Society for Atmospheric Environment 32, 175-186 (in Japanese).

636

Inoue M., Ohara T., Katayama M., Murano K., 2005. Annual source-receptor 638 relationships of sulfur in East Asia using a numerical simulation model RAMS/HYPACT. Journal of Aerosol Research 20 (4), 333-344 (in Japanese).

640

641

Japan

Meteorological

Agency,

Available

at:

642 http://www.seisvol.kishou.go.jp/tokyo/320_Miyakejima/320_So2emission.htm 643 (2012. 1. 2) (in Japanese). 
647 http://www.env.go.jp/en/earth/acid/monitoring/ltadm.pdf (2011.10.1).

648

649

650

651

652

653

654

655

656

657

658

659

660

661

662

663

664

665

666

667

668

669

670

671

672

673

674

675

676

Japanese Ministry of the Environment, 2009. Data report of long-term acid deposition monitoring. Available at: http://www.env.go.jp/earth/acidrain/index.html (2011.10.1) (in Japanese).

Kajino M., Ueda H., Satsumabayashi H., An J., 2004. Impacts of the eruption of Miyakejima Volcano on air quality over far East Asia. Journal of Geophysical Research 109, D21204, doi:10.1029/2004JD004762.

Kalnay E., Kanamitsu M., Kistler R., Collins W., Deaven D., Gandin L., Iredell M., Saha S., White G., Woollen J., Zhu Y., Leetmaa A., Reynolds R., Chelliah M., Ebisuzaki W., Higgins W., Janowiak J., Mo K.C., Ropelewski C., Wang J., Jenne R., Joseph D., 1996. The NCEP/NCAR 40-year reanalysis project. Bulletin of the American Meteorological Society 77, 437-471.

Kistler R., Collins W., Saha S., White G., Woollen J., Kalnay E., Chelliah M., Ebisuzaki W., Kanamitsu M., Kousky V., Dool H.V.D., Junne R., Fiorino M., 2001. The NCEP-NCAR 50-year reanalysis: monthly means CD-ROM and documentation. Bulletin of the American Meteorological Society 82, 247-267.

Krug E.C., Frink C.R., 1983. Acid rain on acid soil: a new perspective. Science 221, 520-525.

Kurokawa J., Ohara T., Uno I., Hayasaki M., Tanimoto H., 2009. Influence of meteorological variability on interannual variations of springtime boundary layer ozone over Japan during 1981-2005. Atmospheric Chemistry and Physics 9, 6287-6304.

Likens G.E., Driscoll C.T., Buso D.C., 1996. Long-term effects of acid rain: 
677 response and recovery of a forest ecosystem. Science 272 (5259), 244-246.

678

679 Likens G.E., Butler T.J., Buso D.C., 2001. Long- and short-term changes in 680 sulfate deposition: effects of the 1990 clean air act amendments. 681 Biogeochemistry 52, 1-11.

682

683 Lin M., Oki T., Bengtsson M., Kanae S., Holloway T., Streets D.G., 2008. 684 Long-range transport of acidifying substances in East Asia -Part II 685 Source-receptor relationships. Atmospheric Environment 42, 5956-5967.

686

687 Lu Z., Streets D.G., Zhang Q., Wang S., Carmichael G.R., Cheng Y.F., Wei C., 688 Chin M., Diehl T., Tan Q., 2010. Sulfur dioxide emissions in China and sulfur 689 trends in East Asia since 2000. Atmospheric Chemistry and Physics 10, 690 6311-6331, doi:10.5194/acp-10-6311-2010.

691

692 Lu Z., Zhang Q., Streets D.G., 2011. Sulfur dioxide and primary 693 carbonaceous aerosol emissions in China and India, 1996-2010. Atmospheric 694 Chemistry and Physics 11, 9839-9864, doi:10.5194/acp-11-9839-2011.

695

696 Morino Y., Ohara T., Kurokawa J., Kuribayashi M., Uno I., Hara H., 2011. 697 Temporal variations of nitrogen wet deposition across Japan from 1989 to 698 2008. Journal of Geophysical Research 116 (D06307), 699 doi:10.1029/2010JD015205.

700

701 Nenes A., Pandis S.N., Pilinis C., 1998. ISORROPIA: a new thermodynamic 702 equilibrium model for multiphase multicomponent inorganic aerosols. 703 Aquatic Geochemistry 4, 123-152.

704

705 Network Center for EANET, 2000a. Technical manual for wet deposition 706 monitoring in East Asia. Available at: 707 http://www.eanet.cc//product/techwet.pdf (2011.10.1). 
709 Network Center for EANET, 2000b. Quality assurance/quality control 710 (QA/QC) program for wet deposition monitoring in East Asia. Available at: http://www.eanet.cc/product/qaqc/qaqcwet.pdf (2011.12.26).

713 Network Center for EANET, 2001. Quality assurance/quality control (QA/QC) program for the air concentration monitoring in East Asia. Available at: http://www.eanet.cc/product/qaqc/qaqcair.pdf (2010.10.1).

Network Center for EANET, 2006. Data report on the acid deposition in the

East Asian region 2000-2005. Available at: http://www.eanet.cc/product.html (2011.12.26).

Ohara T., Akimoto H., Kurokawa J., Horii N., Yamaji K., Yan X., Hayasaka T., 2007. An Asian emission inventory of anthropogenic emission sources for the period 1980-2020. Atmospheric Chemistry and Physics 7, 4419-4444.

Pielke R.A., Cotton W.R., Walko R.L., Tremback C.J., Lyons W.A., Grasso A comprehensive meteorological modeling system -RAMS. Meteorology and Atmospheric Physics 49, 69-91.

Sampattagul S., Kato S., Kiatsiriroat T., Widiyanto A., 2005. Life cycle analytical tools and externalities of the flue gas desulphurization system in Thailand. Chiang Mai University Journal 4 (1), 1-17.

Seto S., Hara H., Sato M., Noguchi I., Tonooka Y., 2004. Annual and seasonal trends of wet deposition in Japan. Atmospheric Environment 38, 3543-3556.

Seto S., Sato M., Tatano T., Kusakari T., Hara H., 2007. Spatial distribution 
Atmospheric Environment 41, 9386-9396.

Shimizu A., Sugimoto N., Matsui I., Arao K., Uno I., Murayama T., Kagawa N., Aoki K., Uchiyama A., Yamazaki A., 2004. Continuous observations of Asian dust and other aerosols by polarization lidars in China and Japan during ACE-Asia. Journal of Geophysical Research 109 (D19S17), doi:10.1029/2002JD003253.

Stern D.I., 2005. Global sulfur emissions from 1850 to 2000. Chemosphere 58, 748 $163-175$.

749

Streets D.G., Waldhoff S.T., 2000. Present and future emissions of air

pollutants in China: $\mathrm{SO}_{2}, \mathrm{NO}_{\mathrm{x}}$, and $\mathrm{CO}$. Atmospheric Environment 34, 752 363-374.

753

Streets D.G., Bond T.C., Carmichael G.R., Fernandes S.D., Fu Q., He D.,

Klimont Z., Nelson S.M., Tsai N.Y., Wang M.Q., Woo J.-H., Yarber K.F., 2003.

An inventory of gaseous and primary aerosol emissions in Asia in the year 2000. Journal of Geophysical Research 108 (D21), 8809, doi:10.1029/2002JD003093.

Sudo K., Takahashi M., Akimoto H., 2002. CHASER: A global chemical model 761 of the troposphere 1. Model description. Journal of Geophysical Research 107 (D17), 4339, doi:10.1029/2001JD001113.

Topping D., Coe H., McFiggans G., Burgess R., Allan J., Alfarra M.R., Bower 765 K., Choularton T.W., Decesari S., Facchini M.C., 2004. Aerosol chemical characteristics from sampling conducted on the Island of Jeju, Korea during ACE Asia. Atmospheric Environment 38, 2111-2123.

Wesely M.L., 1989. Parameterization of surface resistances to gaseous dry 
770 deposition in regional-scale numerical models. Atmospheric Environment 23, $771 \quad 1293-1304$.

772

773 Yoshida Y., Yumimoto K., Uno I., 2006. Evaluation of meteorological 774 parameters over East Asia simulated by regional the meteorological model, 775 RAMS. Journal of Japan Society for Atmospheric Environment 41 (5), $776 \quad 235-248$ (in Japanese).

777 


\section{Figure captions}

Fig. 1. Spatial distribution of $\mathrm{SO}_{2}$ emissions (averaged from 2001 to 2005) used in the CMAQ CTM for East Asia. Circles indicate locations of

Fig. 2. Scatter plots of modeled versus observed annual (a) mean rates of wet deposition of nss- $\mathrm{SO}_{4}{ }^{2-}$, (b) volume-weighted mean concentrations of $\mathrm{nss}^{-\mathrm{SO}_{4}}{ }^{2-}$ in precipitation, (c) precipitation, (d) gaseous $\mathrm{SO}_{2}$ concentrations, and (e) particulate $\mathrm{SO}_{4}{ }^{2-}$ concentrations, from 2000 to 2005 . The solid and open symbols indicate remote and rural sites, respectively. $1: 1,1: 2,2: 1,1: 5$, and 5:1 reference lines are shown. Observed data with temporal coverage of 7 months or more in each year were plotted (see Table 1). Annual means of simulated data were determined as an average over the period for which observed data were available.

Fig. 3. Observed and modeled monthly rates of wet deposition of nss- $\mathrm{SO}_{4}{ }^{2-}$ at representative EANET monitoring sites from 2000 to 2005; these data show seasonal variations (indicated by annotations $\mathrm{M}$ and $\mathrm{S}$ for March and September, respectively). Observed and modeled 
monthly levels of precipitation at each site are also shown. The spatial distribution of annual wet deposition rate of $\mathrm{nss}^{-} \mathrm{SO}_{4}{ }^{2-}$ averaged from 2000 to 2005 is also indicated.

Fig. 4. Scatter plots of modeled versus observed seasonal means of rates of wet deposition of nss- $\mathrm{SO}_{4}{ }^{2-}$ for (a) spring, (b) summer, (c) autumn, and (d) winter from 2000 to 2005. The solid and open symbols indicate remote and rural sites, respectively. 1:1, 1:2, 2:1, 1:5, and 5:1 reference lines are shown. Observed data with temporal coverage of 2 months or more in each season were plotted. Seasonal means of simulated data were determined as an average over the period for which observed data were available.

Fig. 5. Time series from 1988 to 2005 of (a) monthly rates of wet deposition of nss- $\mathrm{SO}_{4}{ }^{2-}$ in Japan obtained from long-term acid deposition monitoring data and modeled data, (b) annual means from the same data sets, and (c) monthly precipitation in Japan from the same data sets. The blue and red shading in (b) signifies standard deviation of data at all observation sites and data at all grids over observation sites, respectively.

Fig. 6. Interannual variations from 1981 to 2005 of (a) sulfur deposition rates in Japan (see Fig. 1) differentiated by source, (b) $\mathrm{SO}_{2}$ emissions in East Asia, and (c) sulfur inflows over the western edge of Japan (see Fig. 1) differentiated by source. In (a) and (c), percentages for contributions from China, wet deposition, and particulate nss- $\mathrm{SO}_{4}{ }^{2-}$ are also shown.

Fig. 7. Relationship from 1981 to 2005 between deposition in Japan of sulfur originating from China and $\mathrm{SO}_{2}$ emissions in China. The linear regression of data from this study (annual amount) is also shown. 
Seasonal values represent average seasonal values for 1981 to 2005 multiplied by 4 . The rate of sulfur deposition in Japan was scaled, multiplying by the ratio of the land area of Japan $(377,880$ $\mathrm{km}^{2}$ ) to the area of Japan defined in each study. The studies shown as red symbols had explicit definitions of the area of Japan. The study shown as green symbol allowed us to read the area of Japan from a figure without explicit definition. The studies shown as light gray symbols did not indicate the area of Japan clearly.

Fig. 8. Spatial distributions of average annual rate of sulfur deposition in East Asia for 5-year intervals between 1981 and 2005. Dashed purple contours (20\% interval) in (a)-(e) show the contribution of anthropogenic emissions from China and those in (f) show the contribution (10\% interval) from Miyakejima volcano. Vectors indicate average wind field below $1116 \mathrm{~m}$. The definitions of B, C, W, S, G, and triangle are explained in Fig. 1.

Fig. 9. Spatial distributions averaged for 1981 to 2005 of (a) annual sulfur deposition (dashed purple contours indicate the percentage of China's contribution), (b) percentage of increase rate in annual amount of sulfur deposition (dashed purple contours indicate the percentage of China's contribution), (c) percentage of wet deposition in total sulfur deposition (d) annual precipitation amount, and (e) share of the increase in wet deposition to increase in total sulfur deposition. White areas in (b), (c) and (e) indicate values of less than 10 in (a) The definitions of B, C, W, S, G, and triangle are explained in Fig. 1.

Fig. 10. Spatial distributions of average (1981-2005) seasonal (a)-(d) rates of sulfur deposition (dashed purple contours indicate seasonal precipitation amount in mm per 3 months); (e)-(h) percentage of 
annual change rate in seasonal amount of sulfur deposition; and (i)-(l) share of the increase in wet deposition to the increase in annual sulfur deposition. White areas in (e)-(h), and (i)-(l) indicate areas where values were less than 2 in (a)-(d). MAM, JJA, SON, and DJF indicate March-May, June-August, September-November, and December-February, respectively. Vectors indicate average wind field below $1116 \mathrm{~m}$. The definitions of B, C, W, S, G, and triangle are explained in Fig. 1.

Fig. 11. (a) Vertical profiles of sulfur concentrations over Japan and (b) annual sulfur flux across the western edge of Japan (Fig. 1) during 1981-1985. (c) and (d) as above but for 2001-2005. Percentages of contributions from China and of particulate $\mathrm{nss}^{-} \mathrm{SO}_{4}{ }^{2-}$ in total sulfur are also shown.

Table 1. Details of EANET site locations (see Fig. 1) and available data.

Table 2. Ratios of simulated to observed values at each station for sulfur and precipitation factors shown in Fig. 2.

Table 3. Total sulfur deposition rate from 1981 to 2005 in East Asia (analytical domain shown in Fig. 1) and contributions of sulfur from Chinese anthropogenic emissions and from the 2000 eruption of Miyakejima volcano.

Table 4. Wet and dry gaseous $\mathrm{SO}_{2}$ and particulate $\mathrm{nss}^{-} \mathrm{SO}_{4}{ }^{2-}$ deposition rates from 1981 to 2005 in East Asia (analytical domain shown in Fig. 1). 


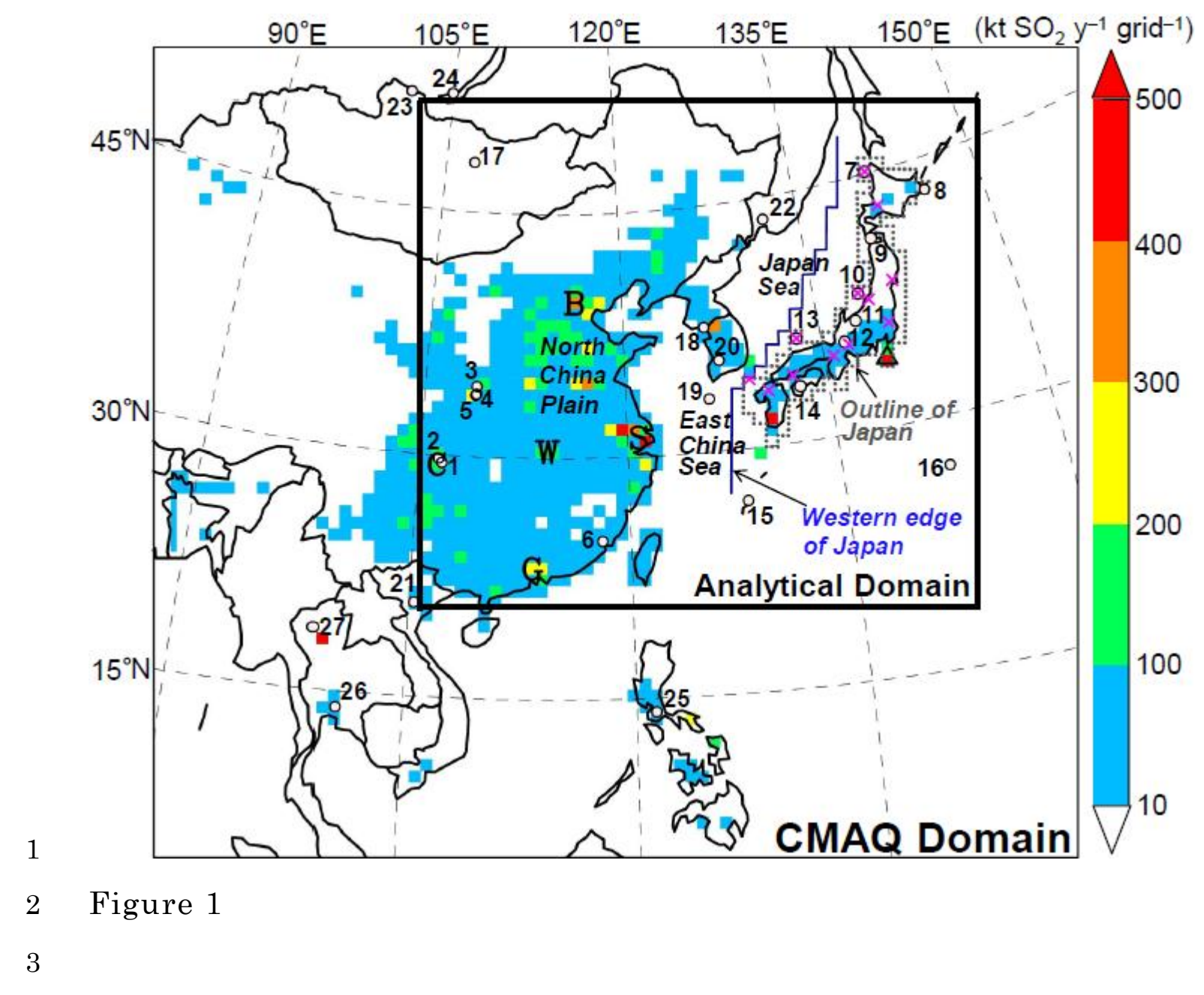



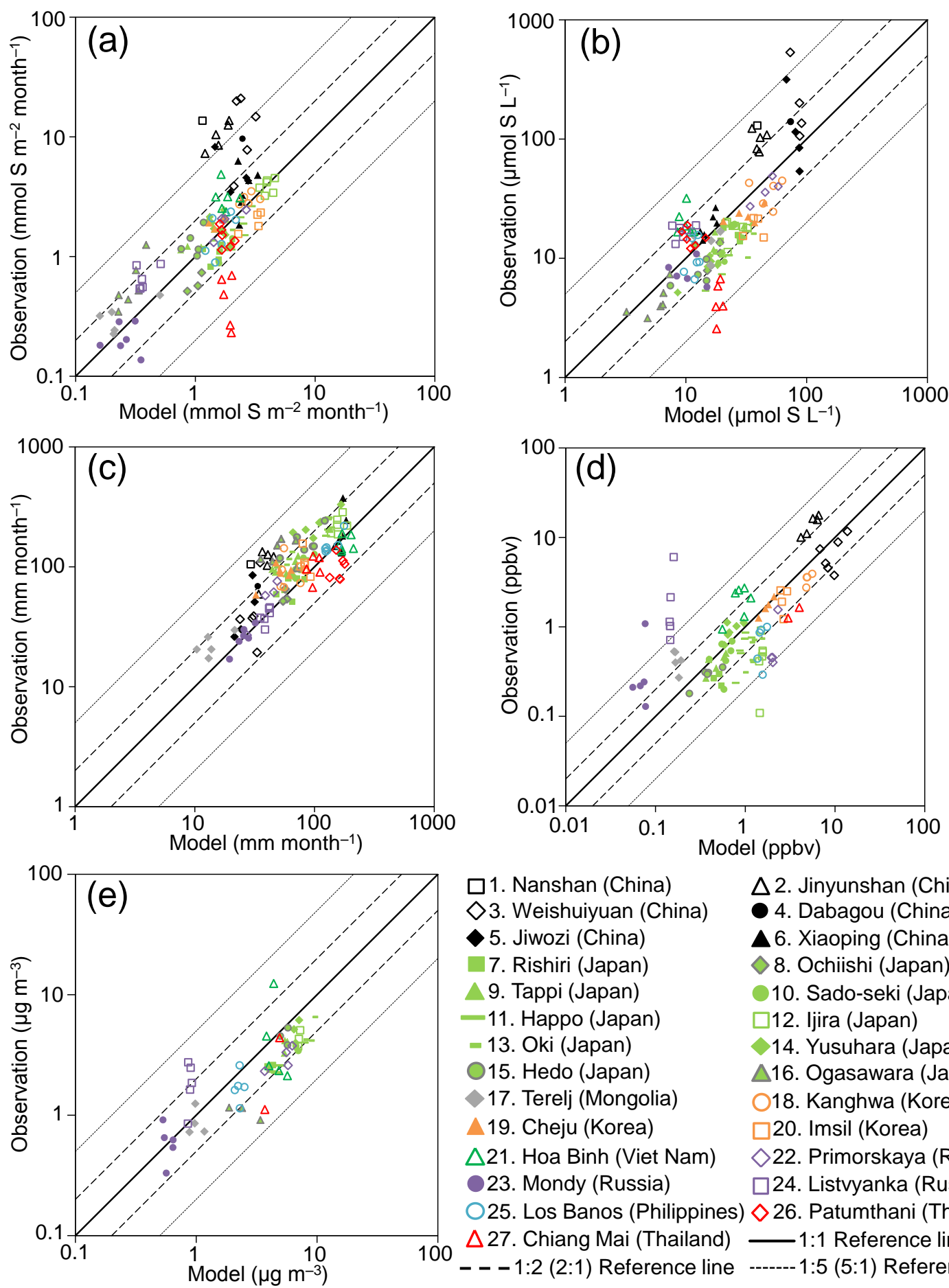

$\square$ 1. Nanshan (China)

$\diamond 3$. Weishuiyuan (China)

5. Jiwozi (China)

7. Rishiri (Japan)

9. Tappi (Japan)

11. Happo (Japan)

13. Oki (Japan)

015. Hedo (Japan)

17. Terelj (Mongolia)

19. Cheju (Korea)

$\triangle 21$. Hoa Binh (Viet Nam)

23. Mondy (Russia)

25. Los Banos (Philippines)

$\triangle 27$. Chiang Mai (Thailand)

- - -1:2 (2:1) Reference line $\triangle 2$. Jinyunshan (China)

- 4. Dabagou (China)

46. Xiaoping (China)

$\checkmark$ 8. Ochiishi (Japan)

10. Sado-seki (Japan)

$\square$ 12. ljira (Japan)

14. Yusuhara (Japan)

$\triangle 16$. Ogasawara (Japan)

18. Kanghwa (Korea)

$\square$ 20. Imsil (Korea)

$\diamond 22$. Primorskaya (Russia)

$\square$ 24. Listvyanka (Russia)

$\diamond 26$. Patumthani (Thailand) 1:1 Reference line $-1: 5$ (5:1) Reference line

5

Figure 2 


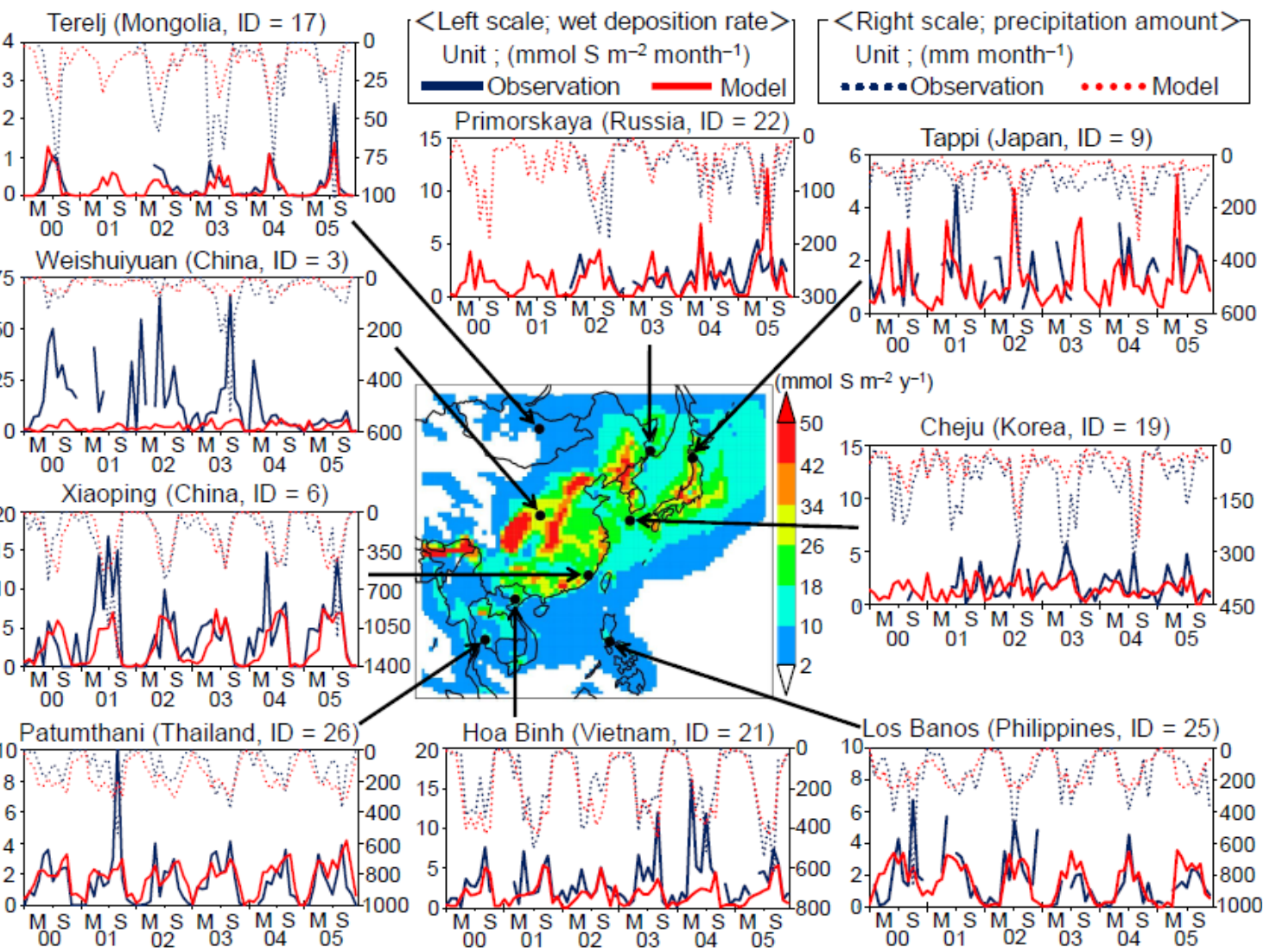

8 Figure 3 

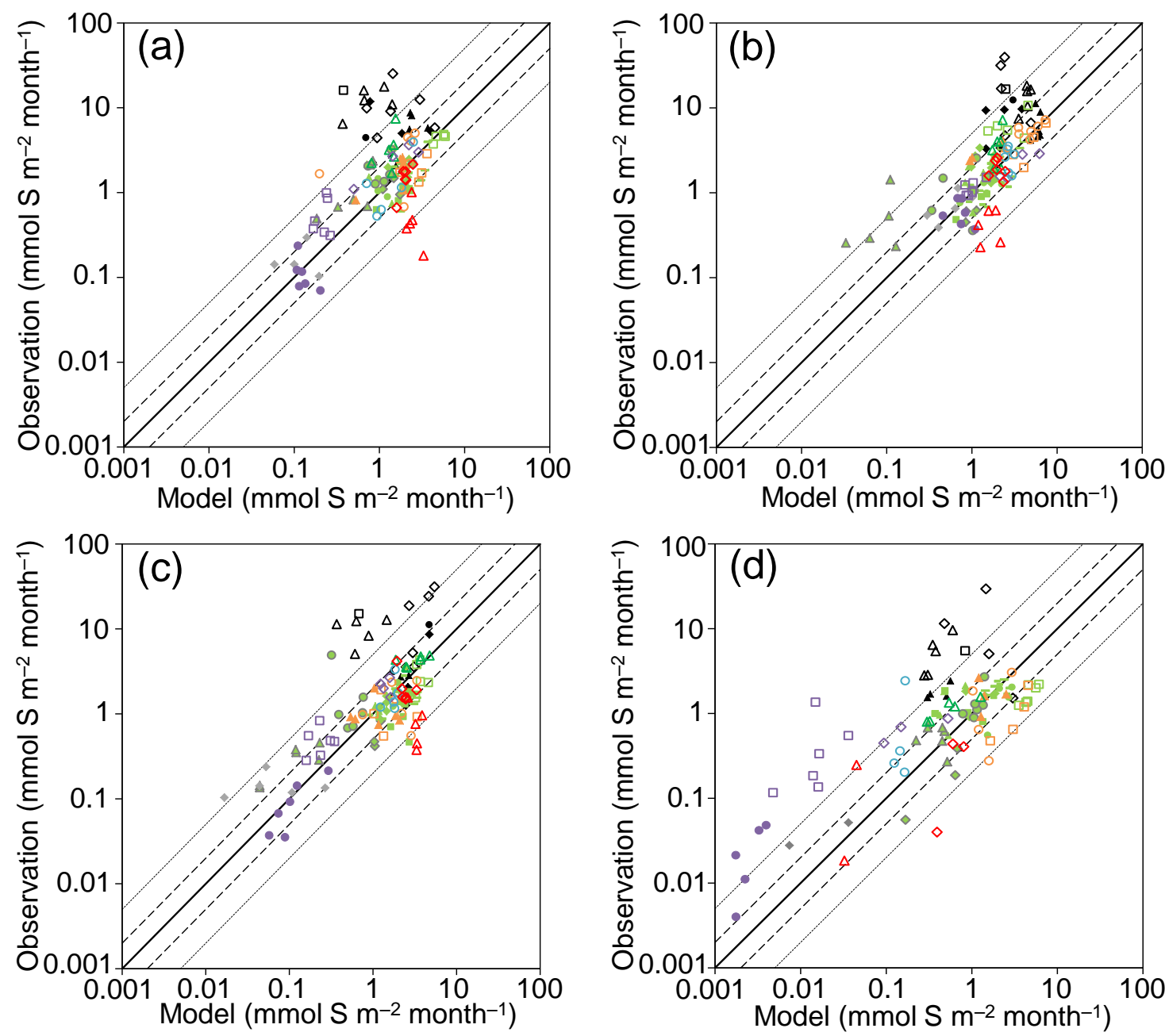

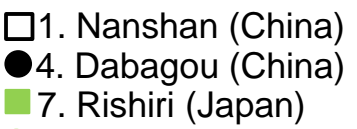

10. Sado-seki (Japan)

-13. Oki (Japan)

$\triangle 16$. Ogasawara (Japan)

19. Cheju (Korea)

$\checkmark 22$. Primorskaya (Russia)

225. Los Banos (Philippines)

1:1 Reference line $\triangle 2$. Jinyunshan (China)

5. Jiwozi (China)

8. Ochiishi (Japan)

11. Happo (Japan)

14. Yusuhara (Japan)

17. Terelj (Mongolia)

$\square$ 20. Imsil (Korea)

23. Mondy (Russia)

$\checkmark 26$. Patumthani (Thailand)

$\diamond 3$. Weishuiyuan (China)

$\Delta 6$. Xiaoping (China)

9. Tappi (Japan)

$\square$ 12. ljira (Japan)

015. Hedo (Japan)

18. Kanghwa (Korea)

$\triangle 21$. Hoa Binh (Viet Nam)

$\square$ 24. Listvyanka (Russia)

$\triangle 27$. Chiang Mai (Thailand)

11 Figure 4 

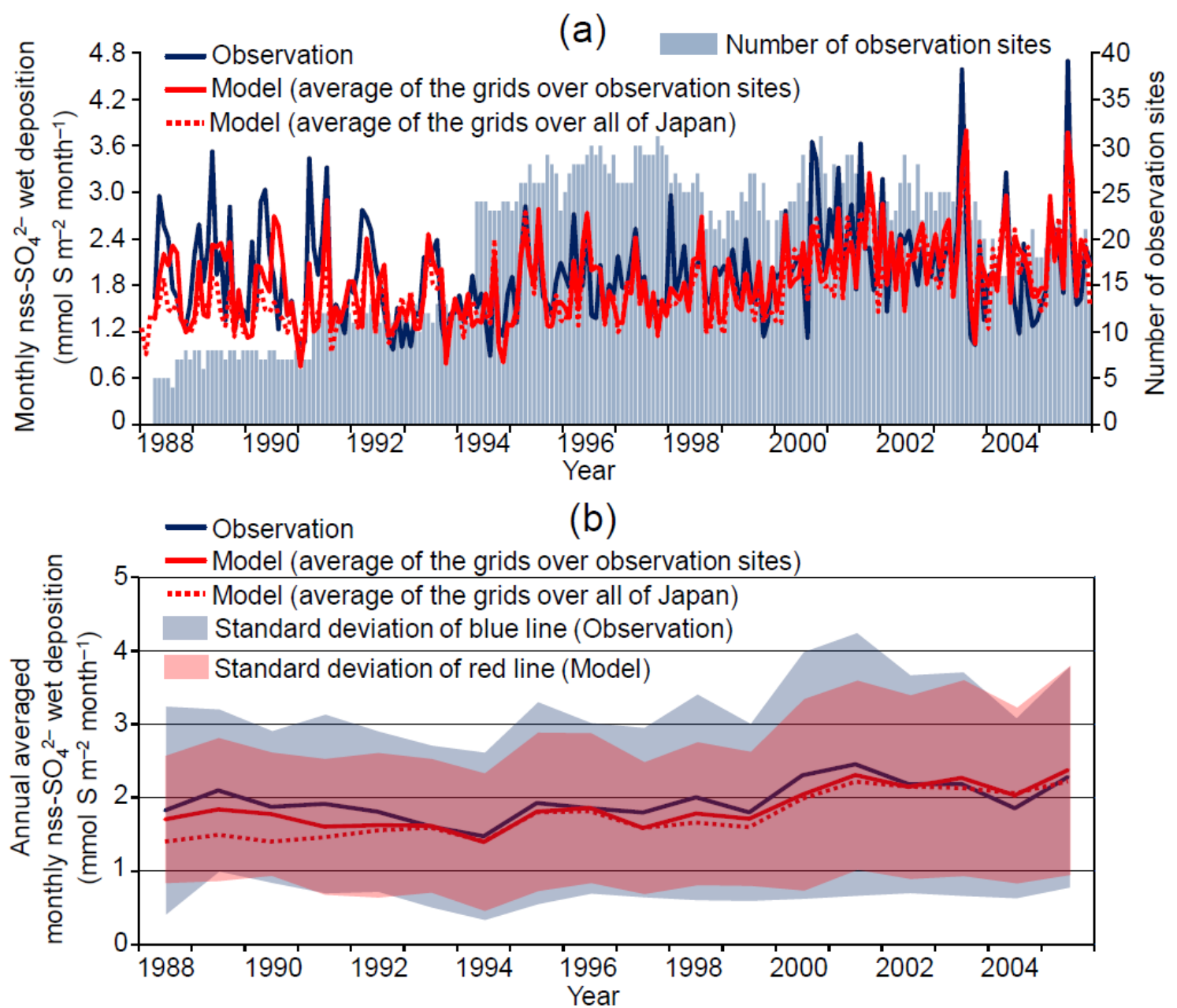

(c)

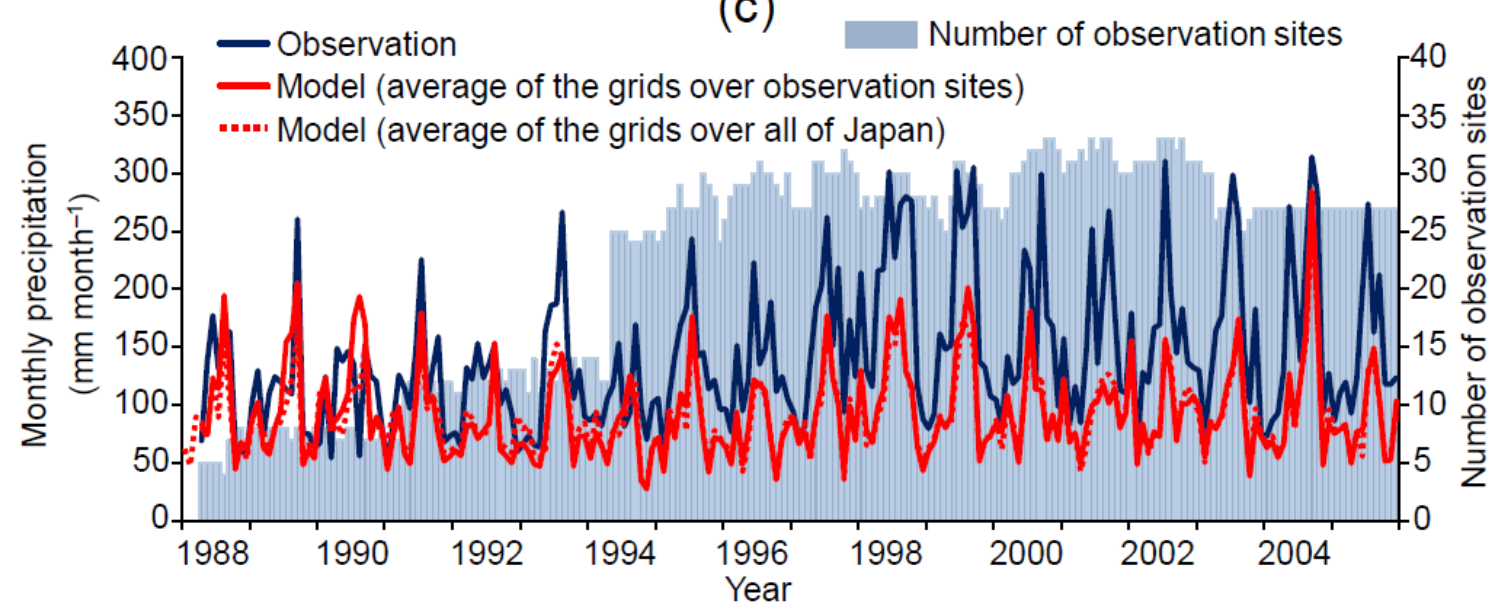

14 Figure 5 

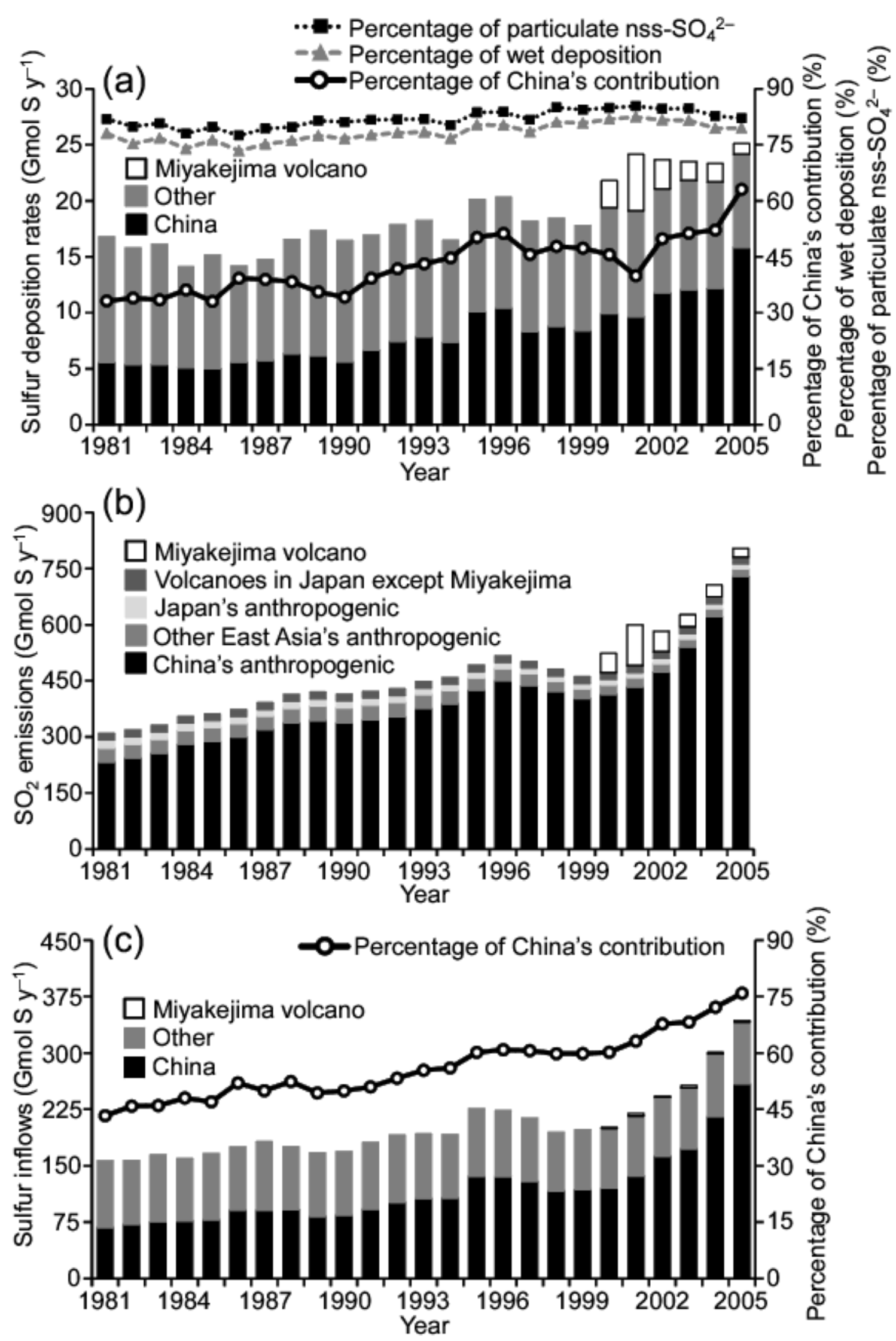

Figure 6 


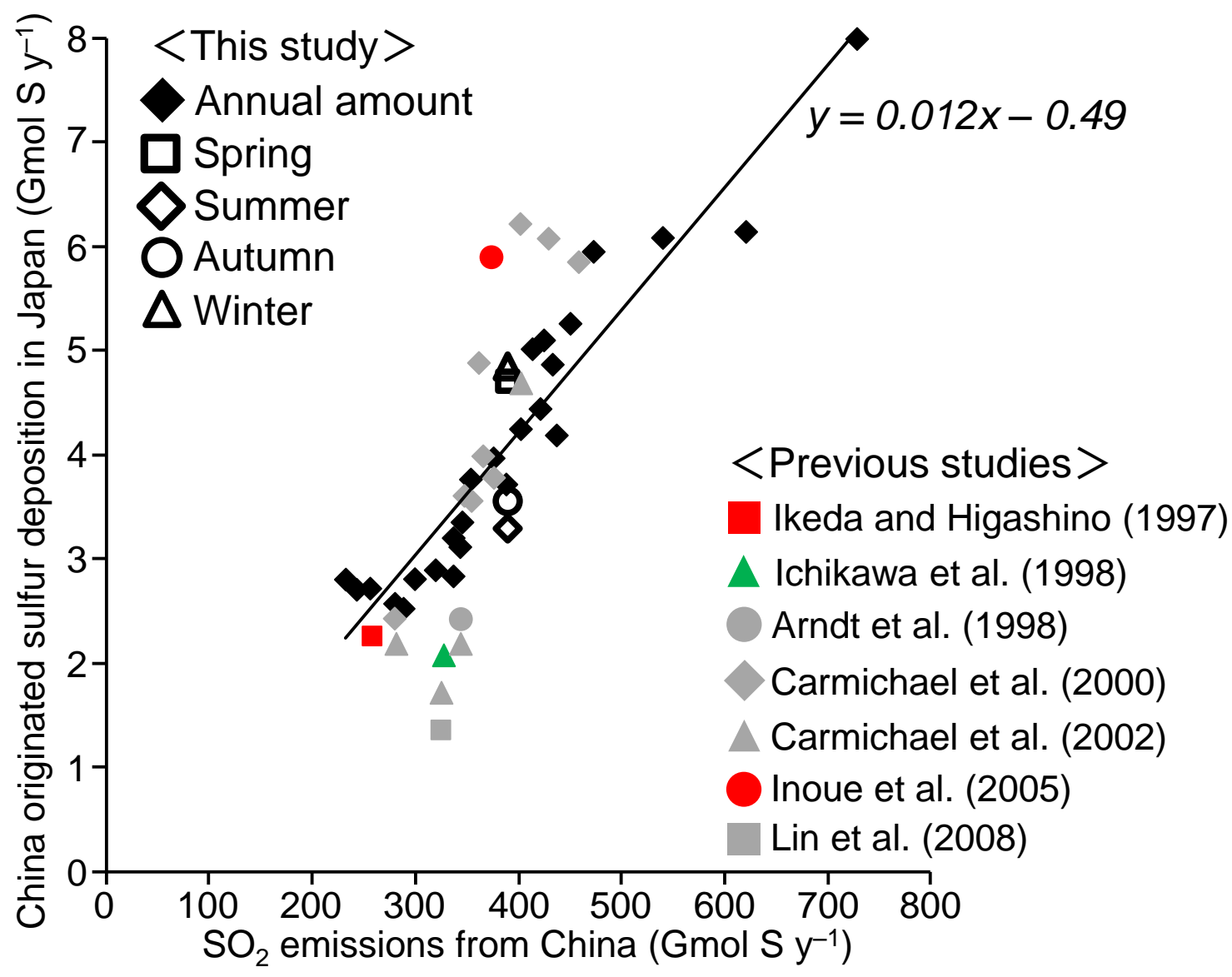

18 Figure 7 

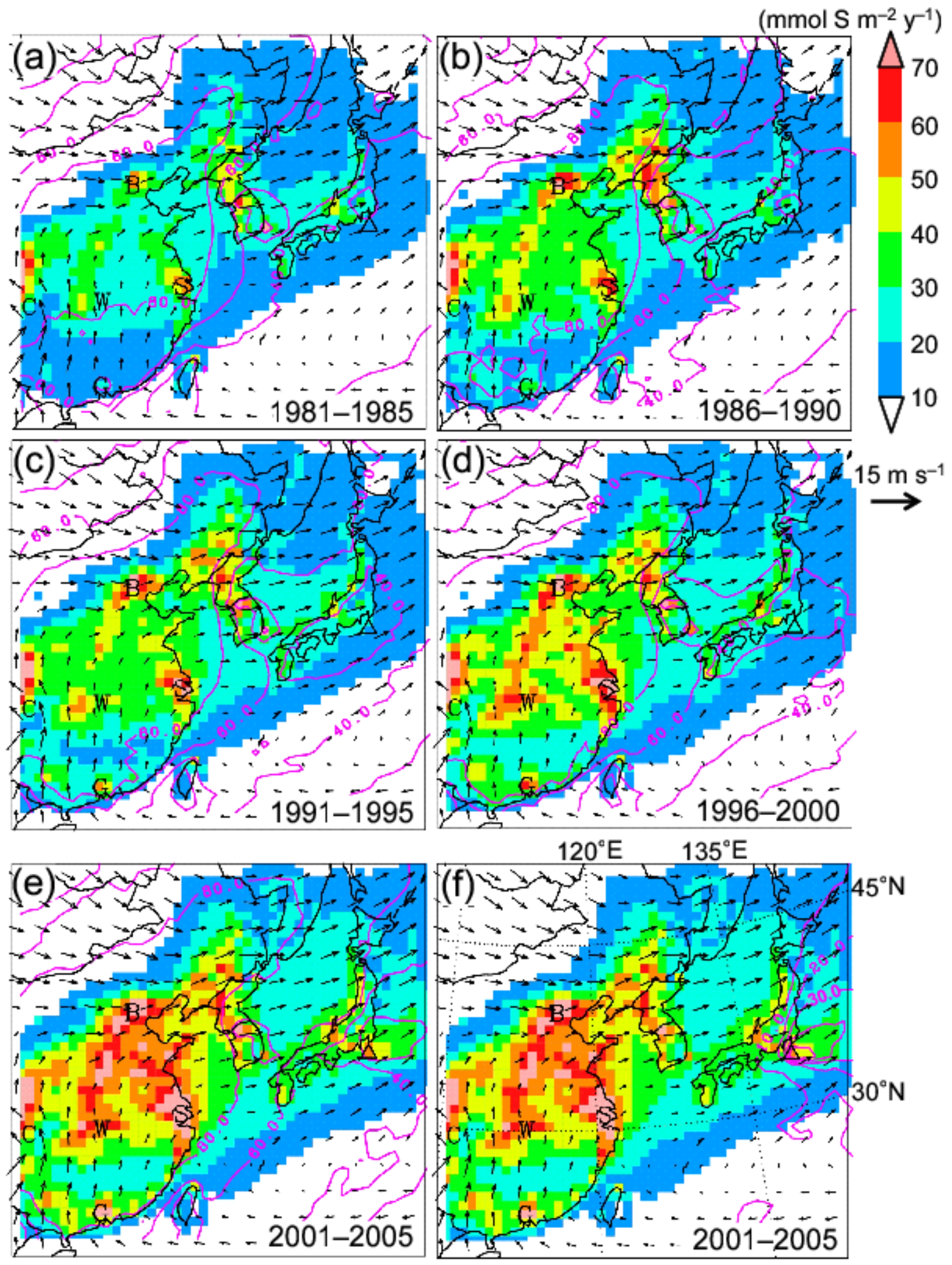

Figure 8 

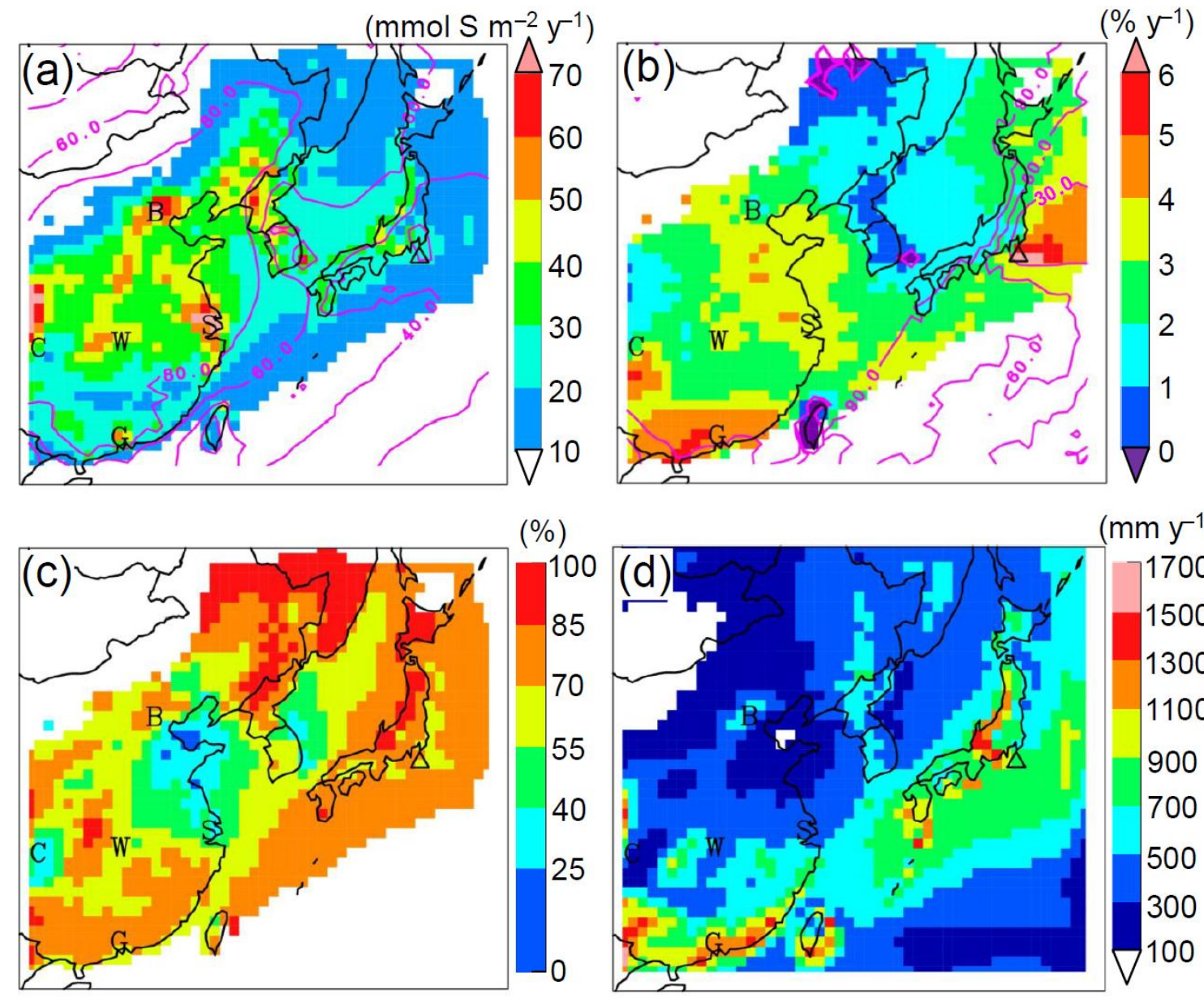

(\%)
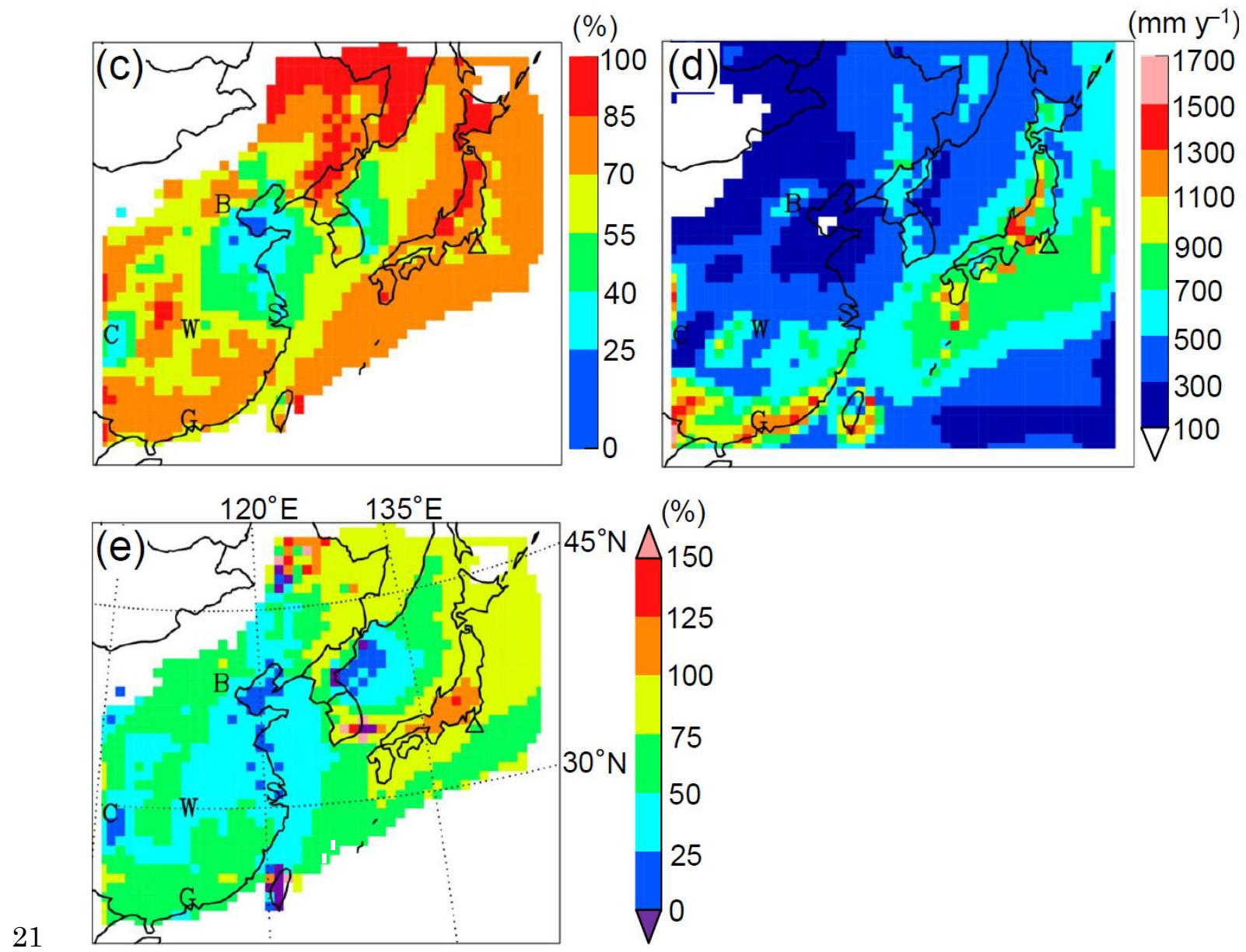

22 Figure 9 


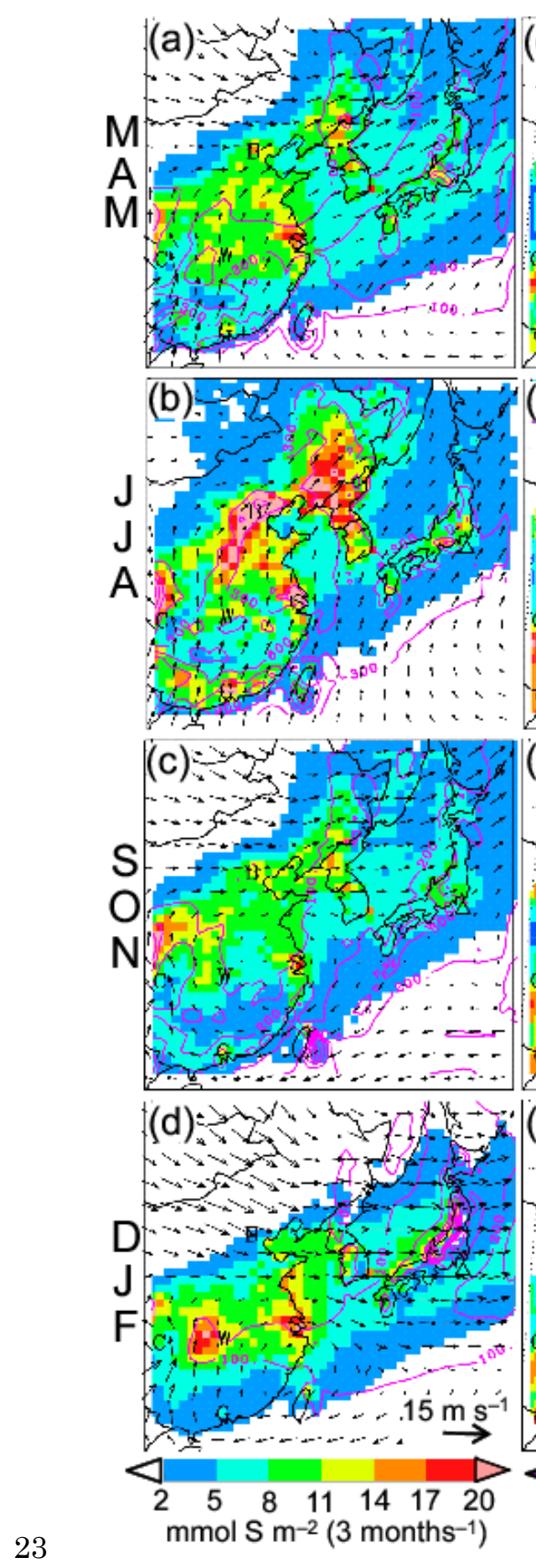

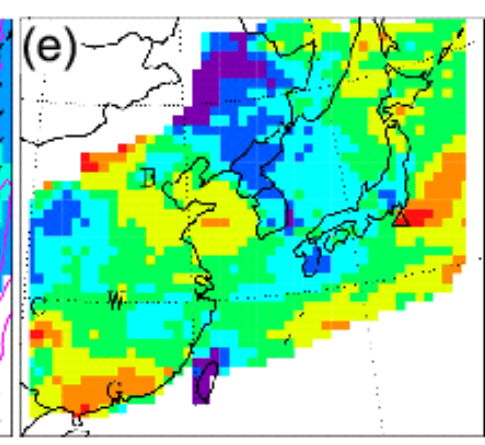
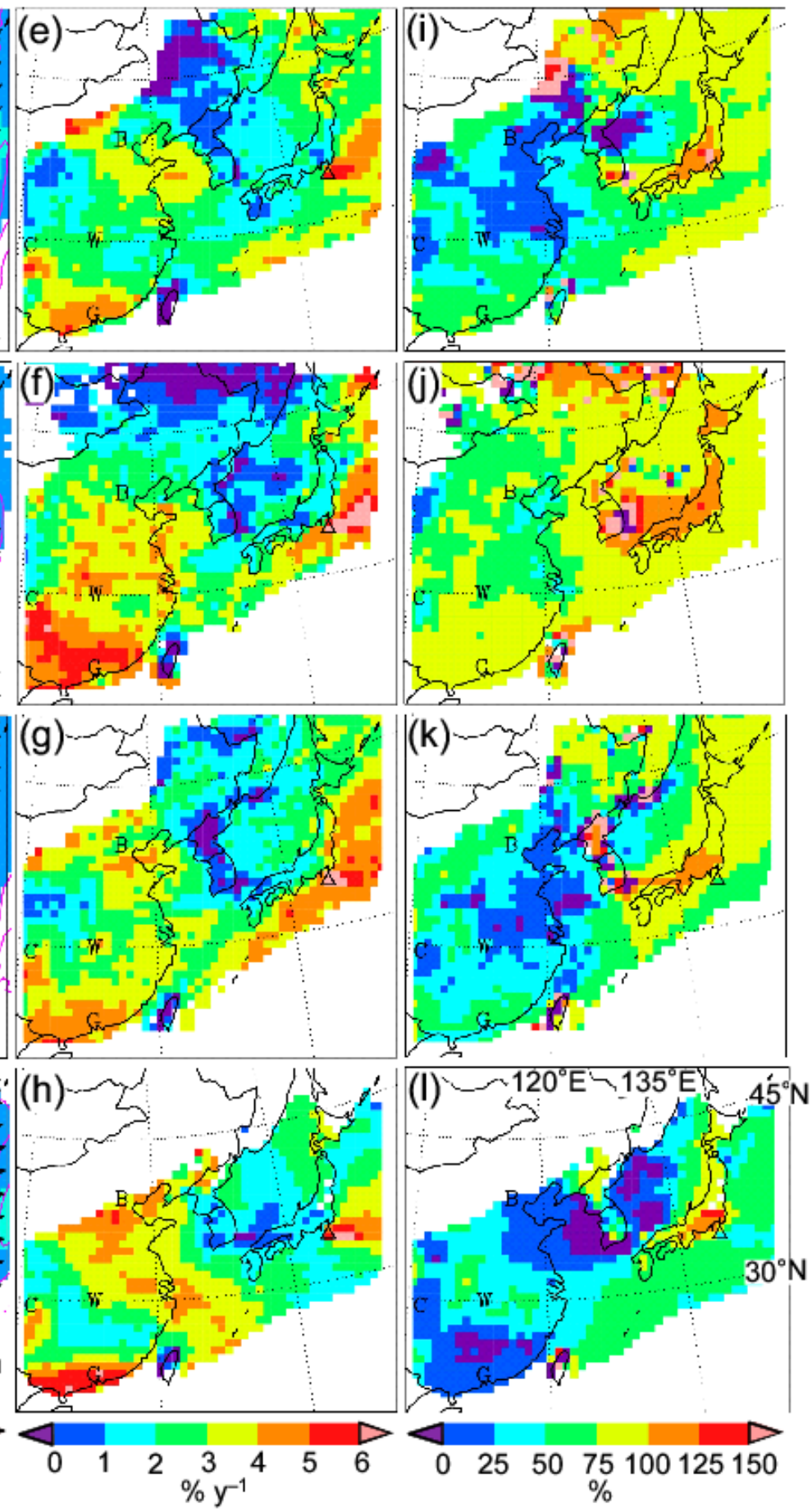

Figure 10 
(a) 1981-1985

Percentage of China's contribution

Percentage of particulate nss- $\mathrm{SO}_{4}{ }^{2-}$

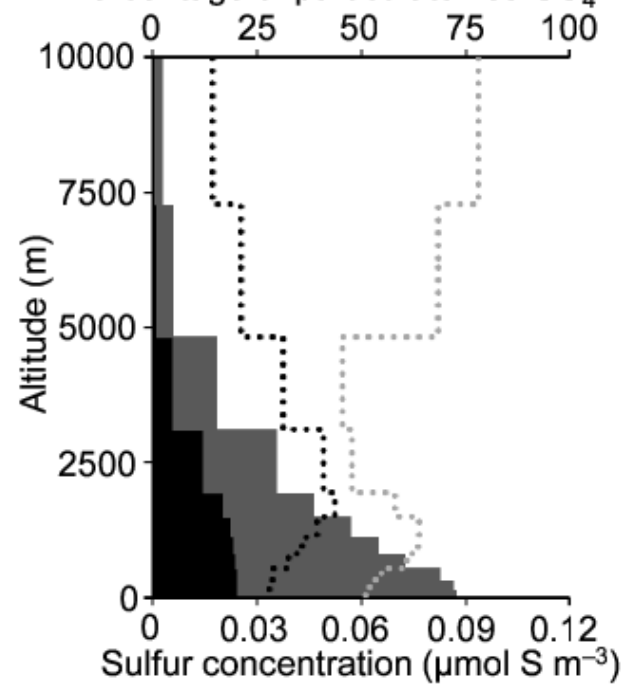

(c) 2001-2005

Percentage of China's contribution Percentage of particulate nss- $\mathrm{SO}_{4}{ }^{2-}$

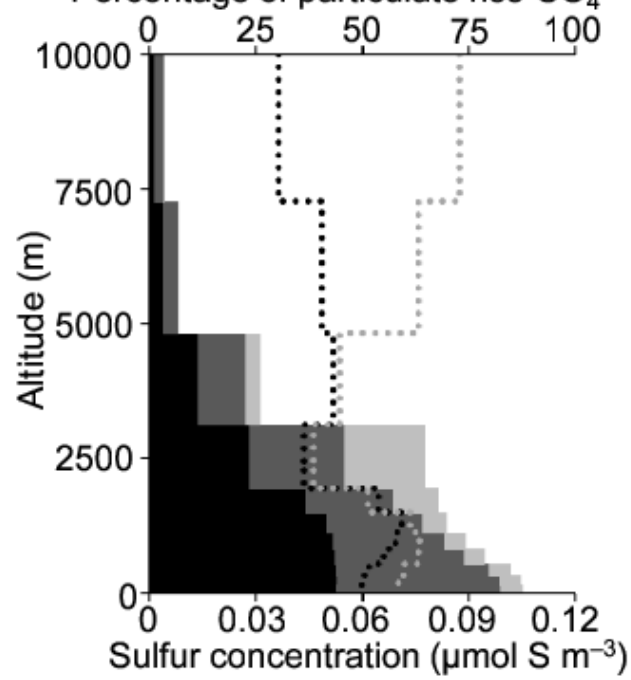

(b) 1981-1985

Percentage of China's contribution

Percentage of particulate nss- $\mathrm{SO}_{4}{ }^{2-}$

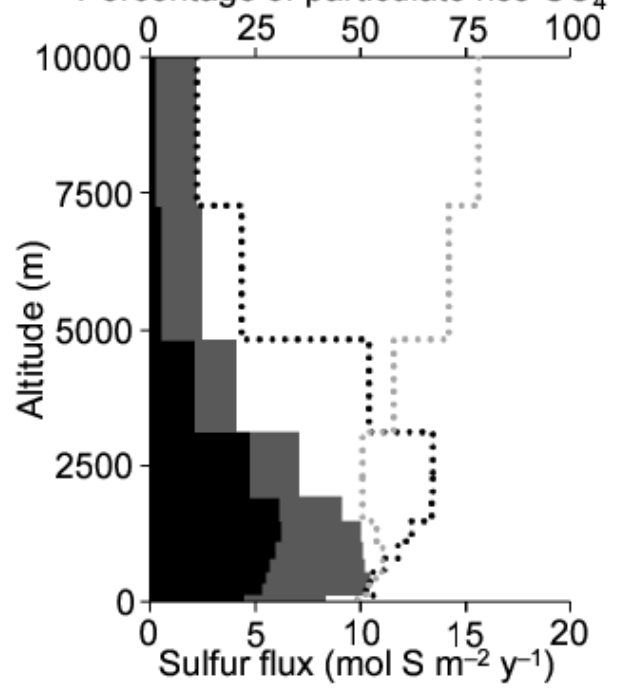

(d) 2001-2005

Percentage of China's contribution

Percentage of particulate nss- $\mathrm{SO}_{4}{ }^{2-}$

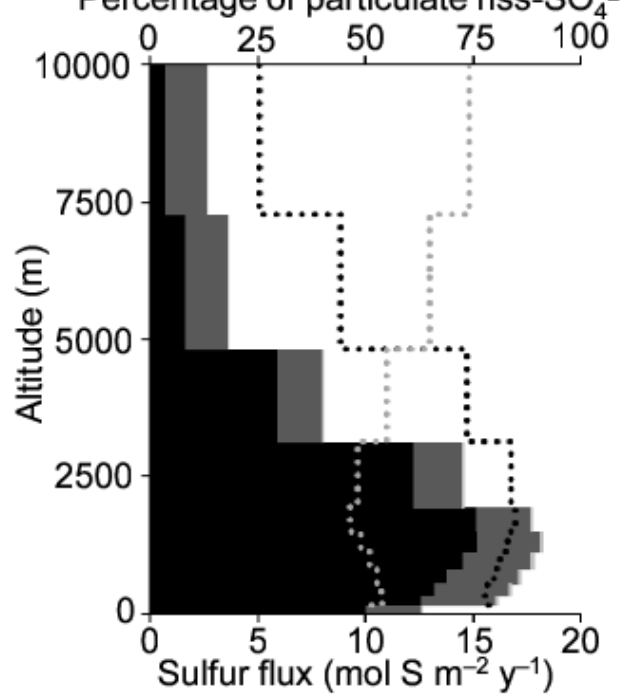

[...Percentage of China's contribution cale $\left[\cdots\right.$ Percentage of particulate nss- $\mathrm{SO}_{4}{ }^{2-}$

Figure 11 
1 Table 1 Details of EANET site locations (see Fig. 1) and available data.

\begin{tabular}{|c|c|c|c|c|c|c|c|c|c|c|}
\hline \multirow{2}{*}{ ID } & \multirow{2}{*}{ Country } & \multirow{2}{*}{\multicolumn{2}{|c|}{ Site name ${ }^{a}$}} & \multirow{2}{*}{$\begin{array}{l}\text { Lat. } \\
\left({ }^{\circ} \mathrm{N}\right)\end{array}$} & \multirow{2}{*}{$\begin{array}{l}\text { Long. } \\
\left({ }^{\circ} \mathrm{E}\right) \\
\end{array}$} & \multirow{2}{*}{$\begin{array}{l}\text { Altitude } \\
\text { (m a.s.l.) }\end{array}$} & \multirow{2}{*}{$\begin{array}{l}\text { Precipitation } \\
\qquad\left(\mathrm{mm} \mathrm{y}^{-1}\right)\end{array}$} & \multicolumn{3}{|c|}{ EANET annual data ${ }^{b}$} \\
\hline & & & & & & & & wet $^{c}$ & $\mathrm{SO}_{2}{ }^{\mathrm{d}}$ & $\mathrm{SO}_{4}{ }^{2-\mathrm{e}}$ \\
\hline 1 & China & Nanshan & $(\mathrm{Ru})$ & 29.55 & 106.63 & 570 & 1259 & 00 & - & - \\
\hline 2 & & Jinyunshan & $(\mathrm{Ru})$ & 29.82 & 106.37 & 800 & 1338 & 01-05 & $01-05$ & - \\
\hline 3 & & Weishuiyuan & $(\mathrm{Ru})$ & 34.37 & 108.85 & 360 & 534 & $00,02-05$ & 00-05 & - \\
\hline 4 & & Dabagou & $(\mathrm{Re})$ & 33.90 & 108.85 & 1200 & 829 & 00 & - & - \\
\hline 5 & & Jiwozi & $(\mathrm{Re})$ & 33.83 & 108.80 & 1800 & 423 & $01,03-05$ & - & - \\
\hline 6 & & Xiaoping & $(\mathrm{Re})$ & 24.85 & 118.03 & 686 & 2283 & 00-05 & - & - \\
\hline 7 & Japan & Rishiri & (Re) & 45.12 & 141.23 & 40 & 892 & 00-05 & $03-05$ & $03-05$ \\
\hline 8 & & Ochiishi & $(\mathrm{Re})$ & 43.15 & 145.50 & 49 & 823 & $03-05$ & - & - \\
\hline 9 & & Tappi & $(\mathrm{Re})$ & 41.25 & 140.35 & 105 & 1168 & 00-05 & 00-05 & $03-05$ \\
\hline 10 & & Sado-seki & $(\mathrm{Re})$ & 38.23 & 138.40 & 136 & 1213 & $00,01,03-05$ & 00-05 & 04,05 \\
\hline 11 & & Нарро & (Re) & 36.68 & 137.80 & 1850 & 2596 & 00-03, 05 & 00-05 & 03-05 \\
\hline 12 & & Ijira & $(\mathrm{Ru})$ & 35.57 & 136.68 & 140 & 2703 & 00-05 & 00-05 & 03-05 \\
\hline 13 & & Oki & $(\mathrm{Re})$ & 36.28 & 133.18 & 90 & 1363 & $00-05$ & $00-05$ & $02-05$ \\
\hline 14 & & Yusuhara & $(\mathrm{Re})$ & 33.37 & 132.93 & 790 & 2736 & $00-05$ & 00-05 & $03-05$ \\
\hline 15 & & Hedo & $(\mathrm{Re})$ & 26.85 & 128.25 & 60 & 2073 & $00-03,05$ & $00-03,05$ & $03-05$ \\
\hline 16 & & Ogasawara & $(\mathrm{Re})$ & 27.08 & 142.22 & 230 & 1612 & 00-05 & - & $03-05$ \\
\hline 17 & Mongolia & Terelj & $(\mathrm{Re})$ & 47.98 & 107.48 & 1540 & 231 & $00,02-05$ & $00,02-05$ & $02-05$ \\
\hline 18 & Korea & Kanghwa & $(\mathrm{Ru})$ & 37.70 & 126.28 & 150 & 1040 & 01-05 & $02-05$ & - \\
\hline 19 & & Cheju & (Re) & 33.30 & 126.17 & 72 & 1084 & $01-05$ & $02-05$ & - \\
\hline 20 & & Imsil & $(\mathrm{Ru})$ & 35.60 & 127.18 & - & 1239 & $02-05$ & $02-05$ & - \\
\hline 21 & Vietnam & Hoa Binh & $(\mathrm{Ru})$ & 20.82 & 105.33 & 23 & 1880 & $00-05$ & $00-05$ & $01-05$ \\
\hline 22 & Russia & Primorskaya & $(\mathrm{Ru})$ & 43.70 & 132.12 & 84 & 700 & $02-05$ & 02-05 & $02-05$ \\
\hline 23 & & Mondy & $(\mathrm{Re})$ & 51.67 & 101.00 & 2000 & 330 & $00-05$ & $00,01,03-05$ & $01-05$ \\
\hline 24 & & Listvyanka & $(\mathrm{Ru})$ & 51.85 & 104.90 & 700 & 445 & $00-05$ & 00-05 & $01-05$ \\
\hline 25 & Philippines & Los Banos & $(\mathrm{Ru})$ & 14.18 & 121.25 & 35 & 2058 & 00-05 & 01-05 & 01-05 \\
\hline 26 & Thailand & Patumthani & $(\mathrm{Ru})$ & 14.03 & 100.77 & 2 & 1268 & 00-05 & - & - \\
\hline 27 & & Chiang Mai & (Ru) & 18.77 & 98.93 & 350 & 1186 & 01-05 & 03,04 & 04,05 \\
\hline
\end{tabular}

$\mathrm{a}(\mathrm{Ru})$ and $(\mathrm{Re})$ indicate rural site and remote site, respectively.

${ }^{\mathrm{b}}$ EANET annual data are limited to years for which at least 7 months of monthly data cleared the EANET criteria for data completeness for 'wet' and the requirement we set about data completeness for ' $\mathrm{SO}_{2}$ ' and ' $\mathrm{SO}_{4}{ }^{2-}$. (c.f. Section 2.2.1).

${ }^{\mathrm{c}}$ Data referred to in 'wet' column are nss- $\mathrm{SO}_{4}{ }^{2-}$ wet deposition, volume-weighted mean concentration of nss-SO ${ }_{4}{ }^{2-}$ in precipitation, and rainfall.

d ' $\mathrm{SO}_{2}$ ' means concentration in air of gaseous $\mathrm{SO}_{2}$.

e $\mathrm{SO}_{4}{ }^{2-1}$ means concentration in air of particulate $\mathrm{SO}_{4}{ }^{2-}$. 
4 Table 2 Ratios of simulated to observed values at each station for sulfur and 5 precipitation factors shown in Fig. 2.

\begin{tabular}{|c|c|c|c|c|c|c|c|c|}
\hline ID & Country & Site name & & $\begin{array}{c}\text { Mean rates of } \\
\text { wet deposition } \\
\text { of nss-SO }{ }_{4}{ }^{2-} \\
\end{array}$ & $\begin{array}{c}\text { Volume-weighted mean } \\
\text { concentrations of } \\
\text { nss-SO }_{4}{ }^{2-} \text { in precipitation }\end{array}$ & Precipitation & $\begin{array}{c}\text { Gaseous } \mathrm{SO}_{2} \\
\text { concentrations }\end{array}$ & $\begin{array}{c}\text { Particulate } \mathrm{SO}_{4}{ }^{2-} \\
\text { concentrations }\end{array}$ \\
\hline$\overline{1}$ & China & Nanshan & $(\mathrm{Ru})$ & 0.08 & 0.30 & 0.28 & - & - \\
\hline 2 & & Jinyunshan & $(\mathrm{Ru})$ & 0.16 & 0.42 & 0.39 & 0.39 & - \\
\hline 3 & & Weishuiyuan & $(\mathrm{Ru})$ & 0.27 & 0.52 & 0.86 & 1.54 & - \\
\hline 4 & & Dabagou & $(\mathrm{Re})$ & 0.26 & 0.53 & 0.48 & - & - \\
\hline 5 & & Jiwozi & $(\operatorname{Re})$ & 0.49 & 0.90 & 0.65 & - & - \\
\hline 6 & & Xiaoping & $(\operatorname{Re})$ & 0.76 & 0.84 & 0.90 & - & - \\
\hline 7 & Japan & Rishiri & $(\operatorname{Re})$ & 1.43 & 1.55 & 0.94 & 1.95 & 1.62 \\
\hline 8 & & Ochiishi & $(\operatorname{Re})$ & 1.68 & 1.69 & 1.01 & - & - \\
\hline 9 & & Tappi & (Re) & 0.77 & 1.41 & 0.56 & 1.23 & 1.45 \\
\hline 10 & & Sado-seki & $(\mathrm{Re})$ & 1.39 & 1.77 & 0.77 & 1.41 & 1.92 \\
\hline 11 & & Happo & $(\operatorname{Re})$ & 1.41 & 2.23 & 0.61 & 1.79 & 1.93 \\
\hline 12 & & Ijira & $(\mathrm{Ru})$ & 1.05 & 1.49 & 0.72 & 4.61 & 1.65 \\
\hline 13 & & Oki & (Re) & 1.03 & 2.01 & 0.52 & 2.32 & 1.81 \\
\hline 14 & & Yusuhara & (Re) & 0.82 & 1.76 & 0.46 & 0.78 & 1.36 \\
\hline 15 & & Hedo & $(\mathrm{Re})$ & 0.77 & 1.54 & 0.54 & 1.32 & 1.22 \\
\hline 16 & & Ogasawara & $(\operatorname{Re})$ & 0.52 & 1.31 & 0.41 & - & 2.48 \\
\hline 17 & Mongolia & Terelj & $(\mathrm{Re})$ & 0.79 & 1.22 & 0.63 & 0.43 & 1.19 \\
\hline 18 & Korea & Kanghwa & $(\mathrm{Ru})$ & 0.93 & 1.43 & 0.74 & 1.47 & - \\
\hline 19 & & Cheju & $(\mathrm{Re})$ & 0.80 & 1.41 & 0.59 & 1.04 & - \\
\hline 20 & & Imsil & $(\mathrm{Ru})$ & 1.58 & 2.10 & 0.79 & 1.42 & - \\
\hline 21 & Vietnam & Hoa Binh & $(\mathrm{Ru})$ & 0.60 & 0.52 & 1.16 & 0.48 & 1.50 \\
\hline 22 & Russia & Primorskaya & $(\mathrm{Ru})$ & 0.95 & 1.26 & 0.77 & 3.82 & 1.78 \\
\hline 23 & & Mondy & $(\mathrm{Re})$ & 1.33 & 1.46 & 1.00 & 0.31 & 1.07 \\
\hline 24 & & Listvyanka & $(\mathrm{Ru})$ & 0.58 & 0.57 & 1.02 & 0.12 & 0.55 \\
\hline 25 & Philippines & Los Banos & $(\mathrm{Ru})$ & 1.10 & 1.22 & 0.91 & 2.70 & 1.39 \\
\hline 26 & Thailand & Patumthani & $(\mathrm{Ru})$ & 1.27 & 0.77 & 1.68 & - & - \\
\hline 27 & & Chiang Mai & $(\mathrm{Ru})$ & 4.99 & 4.53 & 1.05 & 2.54 & 2.22 \\
\hline
\end{tabular}

${ }^{\mathrm{a}}(\mathrm{Ru})$ and $(\mathrm{Re})$ indicate rural site and remote site, respectively. 
8 Table 3 Total sulfur deposition rate from 1981 to 2005 in East Asia 9 (analytical domain shown in Fig. 1) and contributions of sulfur from Chinese 10 anthropogenic emissions and from the 2000 eruption of Miyakejima volcano.

\begin{tabular}{|c|c|c|c|c|c|}
\hline \multirow[b]{2}{*}{ Period } & \multirow{2}{*}{$\begin{array}{c}\text { Total } \\
\text { Deposition rate } \\
\left(\mathrm{mmol} \mathrm{S} \mathrm{m}^{-2} \mathrm{y}^{-1}\right)\end{array}$} & \multicolumn{2}{|c|}{ China's anthropogenic sources } & \multicolumn{2}{|c|}{ Miyakejima volcano } \\
\hline & & $\begin{array}{l}\text { Deposition rate } \\
\left(\mathrm{mmol} \mathrm{S} \mathrm{m}^{-2} \mathrm{y}^{-1}\right)\end{array}$ & $\begin{array}{c}\text { Contribution }^{\mathrm{a}} \\
(\%)\end{array}$ & $\begin{array}{l}\text { Deposition rate } \\
\left(\mathrm{mmol} \mathrm{S} \mathrm{m}^{-2} \mathrm{y}^{-1}\right)\end{array}$ & $\begin{array}{c}\text { Contribution }^{\mathrm{a}} \\
(\%)\end{array}$ \\
\hline 1981-1985 & 14.2 & 9.3 & 65 & - & - \\
\hline 1986-1990 & 16.5 & 11.5 & 70 & - & - \\
\hline 1991-1995 & 17.9 & 13.0 & 73 & - & - \\
\hline 1996-2000 & 20.0 & 14.9 & 75 & - & - \\
\hline 2001-2005 & 24.0 & 18.4 & 77 & 0.8 & 3 \\
\hline 1981-2005 & 18.5 & 13.4 & 72 & - & - \\
\hline
\end{tabular}


13 Table 4 Wet and dry gaseous $\mathrm{SO}_{2}$ and particulate $\mathrm{nss}^{-} \mathrm{SO}_{4}{ }^{2-}$ deposition rates 14 from 1981 to 2005 in East Asia (analytical domain shown in Fig. 1).

\begin{tabular}{|c|c|c|c|c|}
\hline \multirow{3}{*}{ Period } & \multicolumn{2}{|c|}{ Gaseous $\mathrm{SO}_{2}$} & \multicolumn{2}{|c|}{ Particulate $\mathrm{nss}^{-} \mathrm{SO}_{4}{ }^{2-}$} \\
\hline & Wet & Dry & Wet & Dry \\
\hline & \multicolumn{2}{|c|}{$\left(\mathrm{mmol} \mathrm{S} \mathrm{m} \mathrm{y}^{-2}\right)$} & \multicolumn{2}{|c|}{$\left(\mathrm{mmol} \mathrm{S} \mathrm{m} \mathrm{s}^{-2} \mathrm{y}^{-1}\right)$} \\
\hline 1981-1985 & 0.10 & 3.53 & 9.84 & 0.76 \\
\hline 1986-1990 & 0.13 & 4.31 & 11.18 & 0.84 \\
\hline 1991-1995 & 0.12 & 4.80 & 12.08 & 0.88 \\
\hline 1996-2000 & 0.14 & 5.29 & 13.52 & 1.00 \\
\hline 2001-2005 & 0.19 & 7.34 & 15.24 & 1.18 \\
\hline 1981-2005 & 0.14 & 5.05 & 12.37 & 0.93 \\
\hline
\end{tabular}

